\title{
Iberian late-Variscan granitoids: Some considerations on crustal sources and the significance of "mantle extraction ages"
}

\author{
J. Fernández-Suárez ${ }^{\mathrm{a}} *$, G. Gutierrez-Alonso ${ }^{\mathrm{b}}$, S.T. Johnston ${ }^{\mathrm{c}}$,T.E. Jeffries ${ }^{\mathrm{d}}$, D. Pastor-Galán ${ }^{\mathrm{b}}$, \\ G.A. Jenner ${ }^{\mathrm{e}}$, J.B. Murphy ${ }^{\mathrm{f}}$ \\ ${ }^{a}$ Departamento de Petrología y Geoquímica, Universidad Complutense \& IGE-CSIC, 28040 Madrid, Spain \\ ${ }^{\mathrm{b}}$ Departamento de Geología, Universidad de Salamanca, 33700 Salamanca, Spain \\ ${ }^{c}$ School of Earth and Ocean Sciences, University of Victoria, PO Box 3065 STN CSC Victoria, BC V8W 3V6 Canada \\ d Department of Mineralogy. The Natural History Museum, London, United Kingdom \\ e Department of Earth Sciences, Memorial University of Newfoundland, St John's, NF A1B 3X5 Canada \\ ${ }^{\mathrm{f}}$ Department of Earth Science, STFX University, Antigonish, NS B2G 2 W5 Canada
}

\begin{abstract}

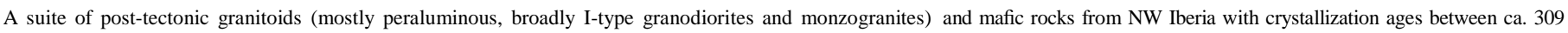

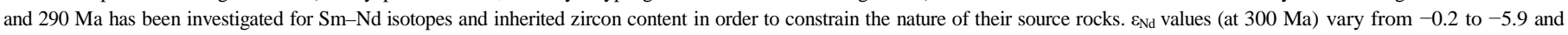

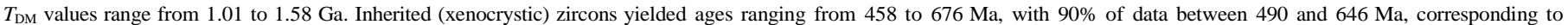

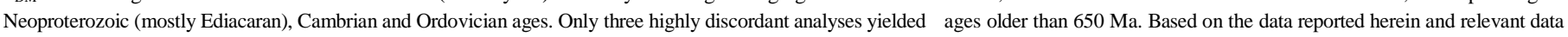

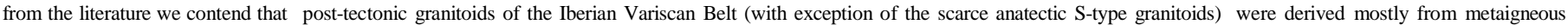

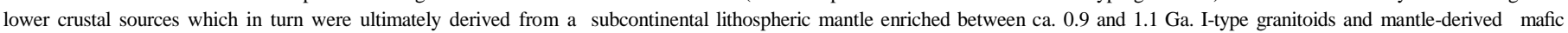

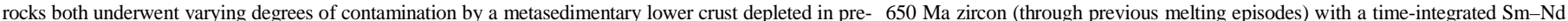

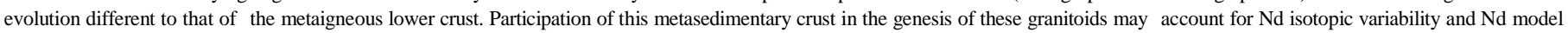
ages well in excess of $1.2 \mathrm{Ga}$.
\end{abstract}

Keywords:

Late Variscan granitoids, Iberian Variscan belt Sm-Nd, isotopes Inherited zircon, Granite sources

\section{Introduction}

The genesis of granitoids and their attendant scenarios, sources and evolution processes are still a matter of intense debate among igneous petrologists. Moreover, granitoid magma can originate by melting of source rocks ranging from the upper crust to the mantle. The generation of granitoid magma takes place at the sites where first order geodynamic processes occur and therefore understanding the petrogenesis of granitoid rocks provides insights into the processes of crustal growth and recycling during Earth's evolution.

In general, we know more about granitoids generated at subduction environments (continental and island arcs) and the causes of their geochemical and isotopic variability are reasonably well constrained. Granitoids generated in collisional orogenesis are more difficult to understand. Calc-alkaline "I-type" granitoids generated in collisional environments pose an important problem.

\footnotetext{
* Corresponding author. Tel.: +34913945013; fax: +34915442535.

E-mail address: jfsuarez@geo.ucm.es (J. Fernández-Suárez).
}

Although they share some of the geochemical characteristics of calc- alkaline granitoids generated in subduction environments, their geodynamic scenario is more complex as is the nature of their crustal sources. In fact, as many granite petrologists would agree, the "granite problem" is really a "source problem" (e.g. Castro, 2004).

The Iberian Variscan Belt (IVB) is an extraordinary example of granite genesis in a post-collisional environment. The so called late- Variscan granitoid suite of Iberia represents a voluminous post-tectonic magmatic event that took place after the main episodes of Variscan collisional deformation. The granitoid plutons belonging to this suite are post-tectonic with respect to the structures/fabrics generated by convergence and subsequent extensional collapse of the orogenic belt. (e.g. Fernandez-Suarez et al., 2000a and references therein). With the exception of volumetrically minor S-type granitoids generated by crustal anatexis at relatively low pressures, the late-Variscan granitoid suite of Iberia is essentially formed by calc-alkaline granodiorites and monzogranites with subordinate amounts of mafic rocks (Villaseca et al., 2009). These granitoids are voluminous compared to the size of the Variscan orogenic belt. They occur across the entire section of the belt including the foreland basin (Cantabrian Zone) although they are 
volumetrically more abundant towards the hinterland at the current level of erosion and exposure (Fernandez-Suarez et al., 2000a and references therein).

In this paper we present geochemical, Sm-Nd isotopic analyses and inherited zircon $\mathrm{U}-\mathrm{Pb}$ ages of a set of samples belonging to the late-Variscan granitoid suite of NW Iberia and we use these data in conjunction with pertinent data from the literature to further investigate the issue of the genesis of post-collisional (late-Variscan) granitoids, their sources and the significance of their $\mathrm{Sm}-\mathrm{Nd}$ isotopic signature.

Our approach aims at providing an understanding of granitoid magma genesis in the wider context of the crustal growth (and recycling) history of a lithospheric unit and the geodynamic scenarios whereby such growth takes place.

\section{Geological setting}

Although heterogeneously deformed by the Late Palaeozoic Variscan Orogeny, Northwestern Iberia exposes one of the most complete sections of the Paleozoic passive margin of northern Gondwana (Fig. 1). In this region, Palaeozoic rocks lie within the tightly curved core of the IberianArmorican Arc (Fig. 1). If this arc is restored to a pre-Variscan geometry (Weil et al., 2001; Weil et al., 2010), the Iberian continental platform of Gondwana is shown to be extremely extensive and locates northwest Iberia adjacent to West
Africa along the southern flank of the Rheic Ocean throughout the Palaeozoic (Robardet, 2002; Robardet, 2003; Martínez Catalán et al., 2007; Nance et al., 2010).

The Palaeozoic rocks of the Iberian Massif are traditionally divided into zones based on differences in their Lower Palaeozoic sedimentary successions, which are interpreted to reflect their relative proximity to the Gondwanan margin (Fig. 1). From the ancient coastline seaward towards the Gondwanan outer platform, five such zones are identified of which three of them have been studied in this work. The Cantabrian Zone (CZ) preserves a coastal environment and constitutes the foreland fold and thrust belt of the IVB, whereas the West Asturian Leonese (WALZ), Central Iberian (CIZ) and Galicia Tras-os-Montes (Schistose Domain) Zones, together with the Ossa-Morena Zone of southern Iberia, preserve a more outboard tectonostratigraphy (Julivert et al., 1972; Quesada, 1990; Ribeiro et al., 1990; Perez Estaun et al., 1991; Quesada, 1991; Martinez Catalan et al., 1997; Gutiérrez- Marco, 1999; Marcos and Farias, 1999; Martínez Catalán et al., 1999; Aramburu, 2002; Robardet, 2002; Robardet, 2003; Robardet and Gutiérrez-Marco, 2004) and contain the geological record of the orogenic hinterland. Boundaries between these zones are major Variscan thrusts and reverse faults that were, in some cases, reactivated by extension in the aftermath of the Variscan Orogeny (Martinez Catalan et al., 1997; Martinez Catalan et al., 2003).

Closure of the Rheic Ocean is recorded in northwest Iberia by the deformation associated with the Laurussia-Gondwana collision, the

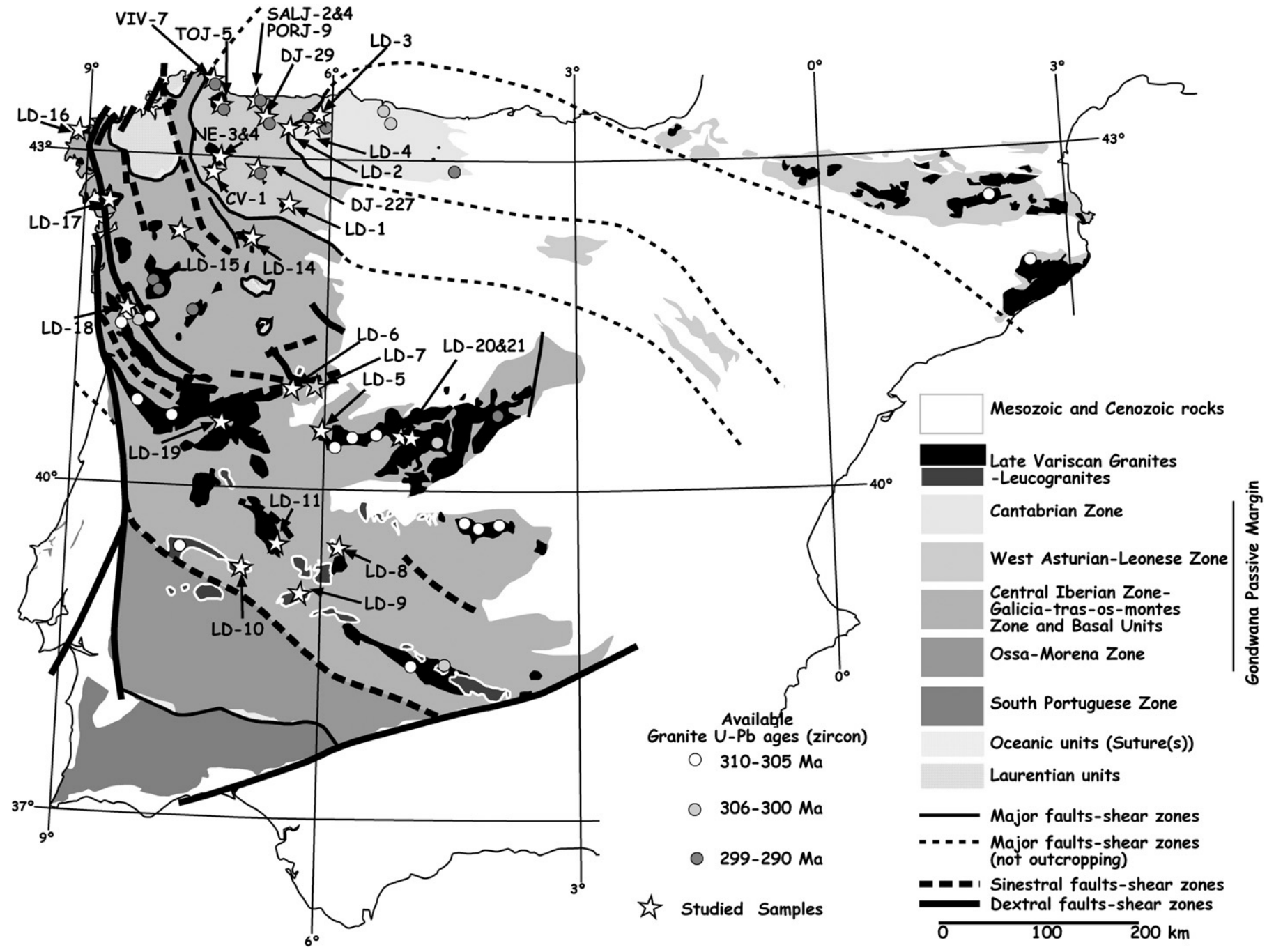

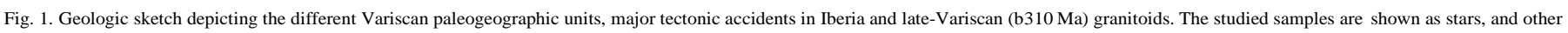
geochronological data of late-Variscan granitoids from the literature are expressed as grey coded circles. 
Variscan Orogeny, and in the oceanic remnants preserved as ophiolites in the suture between these continents (Fig. 1). The earliest evidence of oceanic closure is recorded by northward subduction of the Rheic Ocean along the Laurussian margin, the onset of which occurred before ca. 400 Ma (Dallmeyer and Ibarguchi, 1990; Mendia and Ibarguchi, 1991; Barreiro, 2006; Fernandez-Suarez et al., 2006; Martinez Catalan et al., 2009). Subduction of the Rheic mid-ocean ridge by 395 Ma (Woodcock et al., 2007; Gutierrez-Alonso et al., 2008a) is thought to have caused an increase in the convergence rate and the coupling of both oceanic margins (GutierrezAlonso et al., 2008a).

The onset of continental collision began at ca. 365 Ma (Dallmeyer et al., 1997) with initial subduction of the Gondwana margin (Basal Units) below Laurussia. Deformation of the Gondwanan passive margin succession caused by the subsequent overriding of Gondwana by Laurussia migrated eastward in space and time. Convergence initially produced recumbent folds (D1) that verge and migrate from the suture towards the present-day core of the IberianArmorican Arc. Continued shortening is thought to have led to the extensional collapse (D2) of the thickened orogenic hinterland (Viruete et al., 1994; Arenas and Catalan, 2003; Pereira et al., 2009) at ca. 320 Ma (Martinez Catalan et al., 2009). This event was coeval with the development of a non-metamorphic foreland fold-thrust belt within the Cantabrian Zone (Perez Estaun et al., 1994). Final deformation associated with the closure of the Rheic Ocean (D3) produced largewavelength upright folds and strike-slip ductile shear zones (Martinez Catalan et al., 2009). Immediately following ocean closure, and coevally with the intrusion of the igneous rocks studied herein, an abrupt change in the stressstrain field associated with Pangaea amalgamation caused a dramatic $180^{\circ}$ rotation of the IVB to produce the Iberian-Armorican Arc. The development of the Iberian- Armorican arc was accompanied by a major thermal event that has been interpreted to record Late Carboniferous-Early Permian lithospheric delamination (Fernandez-Suarez et al., 2000a; Weil et al., 2001; Gutiérrez-Alonso et al., 2004; Gutierrez-Alonso et al., 2008a; Weil et al., 2010).

3. Summary of geological and petrological features of the granitoids and geochronological constraints

Granitoids are the main igneous feature of the IVB and they occupy about $15 \%$ of total exposure, with a larger percentage in the hinterland (CIZ) and diminishing quantities towards the foreland (WALZ and the CZ) (Fig. 1). One of the most striking features of the late-Variscan granitoid magmatism is its occurrence in the foreland fold-thrust belt of the orogenic belt, which is a rare feature in collisional orogens (e.g. Fernandez-Suarez et al., 2000a). This paper is focused on the post- collisional (late-Variscan) granitoids whose main exposures in the Cantabrian, Westasturian-Leonese and Central Iberian Zones are shown in Fig. 1. As stated above, the term late-Variscan applies to granitoids whose emplacement postdates the main episodes of crustal shortening related to the Variscan Orogeny and also the subsequent extensional collapse of the orogenic belt. The crystallization ages of these granitoids (based on U-Pb zircon and monazite dates) range from ca. 309 to 290 Ma (Dias et al., 1998; Fernandez-Suarez et al., 2000) and post-date by ca. 20-30 My the peak of migmatisation and crustal melting associated with the extensional collapse of the orogenic belt (Viruete, 1998; Bea et al., 2006; Castineiras et al., 2008).

The late-Variscan granitoid suite is predominantly composed of granodiorite-monzogranite intrusions, minor tonalite and maficintermediate rocks, and leucogranitoid intrusions. The main petro- logical and geochemical features are described below and are illustrated in Figs. 2 to 5. The granodiorite-monzogranite plutons (e.g. Caldas de Reis and Neira in Table 1) are the dominant rock type and are made up of biotite \pm amphibole granodiorite and biotite monzogranite. Amphibole-biotite tonalite and quartzdiorite occur as

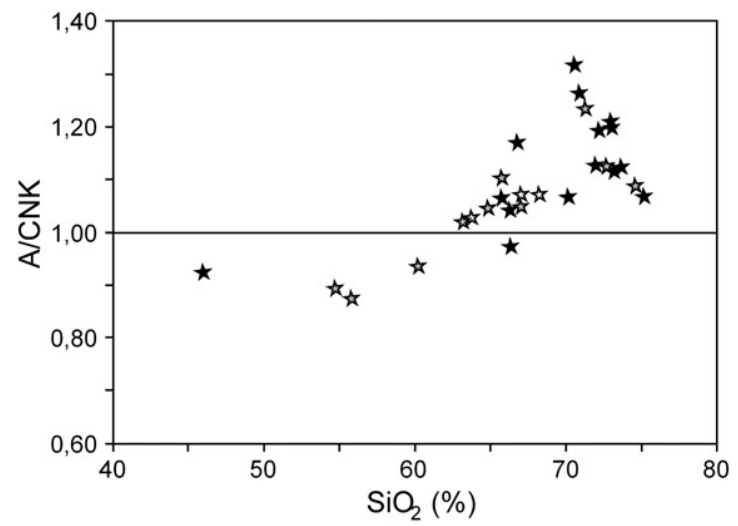

Fig. 2. $\mathrm{SiO}_{2}$ vs. $\mathrm{A} / \mathrm{CNK}$ (molar) diagram of the studied samples. White stars are samples from the Cantabrian zone; grey ones from the West-Asturian Leonese zone; and black ones from the Central Iberian zone.

microgranular enclaves in most plutons. Leucogranitic rocks (e.g. Ancares and Traba in Table 1) include two-mica (usually Ms NBt) or muscovite leucomonzogranites, alkali feldspar granites and aplites occurring as dykes or forming the apical parts of plutons. Micro- granular igneous enclaves are lacking and metasedimentary xenoliths are common.

Mafic rocks (mostly diorites, gabbros and quartz-diorites) are scarce in the late-Variscan igneous suite and occur either as discrete small intrusions (e.g. Porcia and El Alamo in Table 1) or spatially associated to the granodiorite-monzogranite plutons. Although this study focuses on granitoids, Tables 1 and 2 report chemical and isotopic analyses of representative samples from three of these mafic intrusions (samples SALJ-2, PORJ-9 and LD-20) for reference. The petrogenesis of these mafic intrusions has been the object of several detailed studies (Suarez et al., 1990; Morenoventas et al., 1995; Galan et al., 1996; Bea et al., 2006; Orejana et al., 2009) and will not be further described here.

\section{Samples and analytical methods}

Twenty nine samples representing 27 late-Variscan plutons were used for this study. Major, trace and rare earth element analyses were performed on all 29 samples and Sm-Nd isotopes were analysed for 18 samples. In addition, zircons were separated from 20 samples in order to perform a preliminary study of the inherited/xenocrystic zircon component in these granitoids.

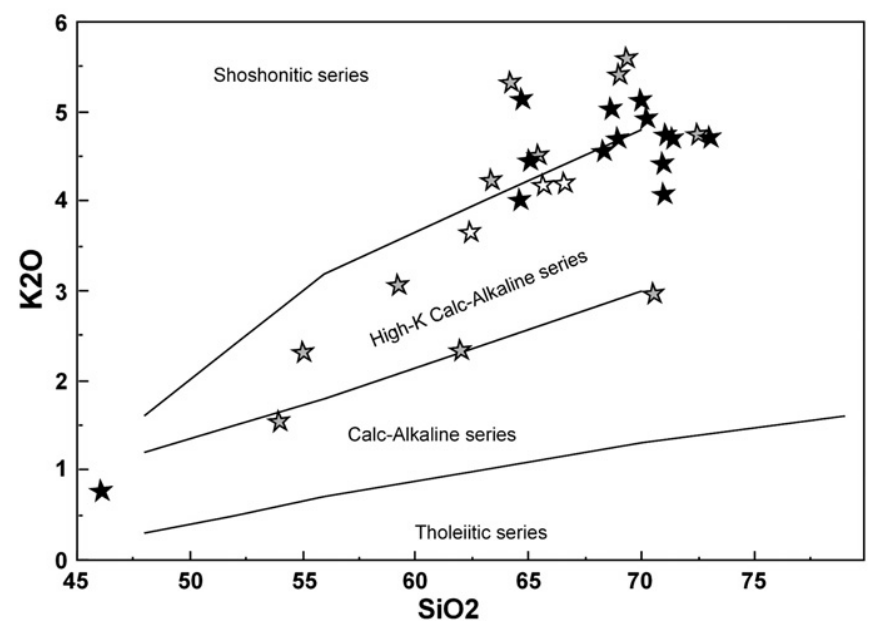

Fig. 3. $\mathrm{K}_{2} \mathrm{O}$ vs. $\mathrm{SiO}_{2}$ (Pecerillo and Taylor, 1976). Stars are grey coded as in Fig. 2. 

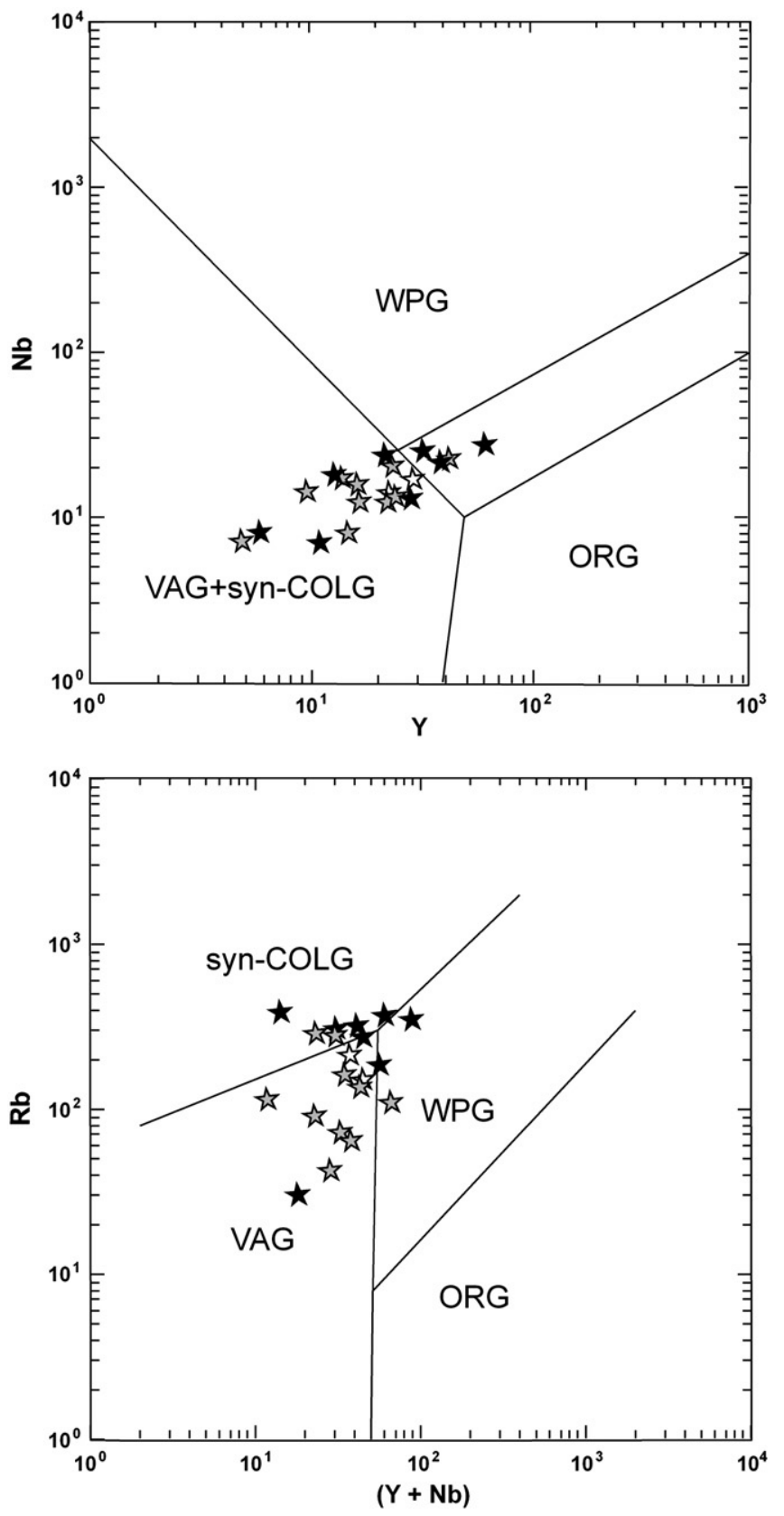

Fig. 4. $\mathrm{Y}$ vs. Nb and $\mathrm{Y}+\mathrm{Nb}$ vs. Rb diagrams (Pearce et al., 1984). Stars are grey coded as in Fig. 2.

The analytical methodology and procedures for major, trace, rare element analyses, Sm-Nd isotopes and $\mathrm{U}-\mathrm{Pb}$ dating of xenocrystic zircon are described in Appendix DR1. The results are shown in Tables 1, 2 and 3 of the DR1 document.

\section{Major and trace element geochemistry}

Of the 29 samples used in this study, one sample is a microgranular mafic enclave in the Neira pluton (sample NE-3), three correspond to minor mafic intrusions (samples SALJ-2, PORJ-9 and LD-20) and the remaining samples are granitoid rocks (biotite \pm amphibole grano- diorites, biotite monzogranites and biotite+ muscovite leucomonzo- granites) (Table 1). As regards their spatial distribution (Fig. 1), 3 samples are from the Cantabrian Zone, 11 from the Westasturian- Leonese Zone and 15 are from the Central Iberian Zone.
Rock/Chondrites

Sun+McDon. 1989-REEs

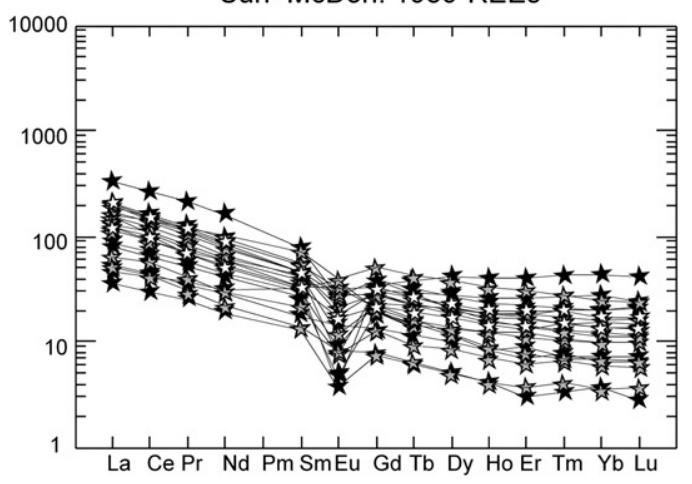

Fig 5. Normalised REE plot for selected samples of granitoids. Normalisation values of (Sun and McDonough, 1989). Stars are grey coded as in Fig. 2.

Leucogranitoids (Table 1, see also Fernández-Suárez, 1994; FernandezSuarez et al., 2000a) are classified as leucomonzogranites and leucogranodiorites. They are peraluminous (A/CNK N 1, Fig. 2) granites with low $\mathrm{Ca}$ and $\mathrm{Mg}$ contents ( $\mathrm{CaOb} 1.3 \%$, MgOb 0.7\%). Following the nomenclature of Debon and Lefort (1988), these granitoids define a leucocratic s.s. (b $7 \%$ dark minerals) high aluminous $(\mathrm{A} \approx 30-90$ ), sodipotassic $(\mathrm{K} /(\mathrm{Na}+\mathrm{K}) \approx 0.3-0.6)$ associ-

ation with vertical trendsin the A-Bdiagram(Fernandez-Suarezetal., 2000a).

The granodiorite-monzogranite intrusions are peraluminous to slightly metaluminous granitoids that define "alumino-cafemic" asso- ciations of calcalkaline type (Debon and Lefort, 1988). The rocks define calc-alkaline trends in modal composition in the QPF diagram of Debon and Le Fort (Fernández-Suárez, 1994; Fernandez-Suarez et al., 2000a). Many of these rocks display some of the characteristic features of infracrustal I-type granitoids: high $\mathrm{Na}, \mathrm{A} / \mathrm{CNK}$ typically b 1.1 (except in differentiated facies), $\mathrm{K}_{2} \mathrm{O} / \mathrm{Na}_{2} \mathrm{O}$ mostly comprised between 1 and 1.5 for granodiorites and monzogranites, presence of amphibole and absence of primary muscovite, associated molybdenum-gold mineralization in some cases. The $\mathrm{K}_{2} \mathrm{O}$ vs. $\mathrm{SiO}_{2}$ plot (Fig. 3) shows the high-K nature of the granitoids. On the basis of their main geochemical features they could be classified as high-K calc-alkaline to shoshonitic granitoids. However, the postcollisional tectonic setting of these granitoids implies that they cannot be readily compared with calc-alkaline granitoids from subduction environments or with the classic I-types as originally described in the Lachlan Fold belt of Australia (e.g. Chappell and White, 1992). In the IVB most late-Variscan granodioritemonzogranite plutons fit the $m P-l P$ (medium-low peraluminous) types of Villaseca et al. (1998) whereas the leucogranitoids fit the fP (felsic peraluminous) type of the above authors.

In tectonic discrimination diagrams (Pearce et al., 1984) shown in Fig. 4, the late-Variscan granitoids plot mostly within the syn- collisional+ volcanic arc granite fields.

These granitoids show in general moderate REE contents and moderately fractionated REE patterns (Fig. 5) with $(\mathrm{La} / \mathrm{Yb})_{\mathrm{N}}$ between ca. 4 and 18 and Eu anomalies with $\mathrm{Eu} / \mathrm{Eu}^{*}$ values ranging from ca. 0.8 to 0.4 (Villaseca et al., 2009).

\section{Nd isotope results}

The Sm-Nd isotopic composition of the 18 samples analysed is given in Table 2 (DR1) and shown in Fig. 6 in an age vs. $\varepsilon_{\mathrm{Nd}}$ diagram. The initial isotopic ratio (expressed in epsilon units, $\varepsilon_{\mathrm{Nd}}$ ) was calculated for an age of $300 \mathrm{Ma}$ as all dated intrusions have crystallization ages ranging from ca. 309 to $290 \mathrm{Ma}$ (see above).

The ${ }^{147} \mathrm{Sm} /{ }^{144} \mathrm{Nd}$ values range between 0.0979 and 0.1480 . The $\varepsilon_{\mathrm{Nd}}$ (at $300 \mathrm{Ma}$ ) varies between -0.2 (microgranular enclave in the Neira 
pluton, sample NE-3) and -5.9 (Braga pluton, sample LD-18). Nd model ages $\left(T_{\mathrm{DM}}\right)$ (DePaolo, 1981; DePaolo, 1988) range between 1.01 and $1.58 \mathrm{Ga}$ (Table 2 and Fig. 6). These results are comparable with those reported in other studies of granitoids belonging to the late-

Variscan igneous suite (e.g. Villaseca et al., 2009). It should be noted that (based on the current data set) there is no apparent correlation of $\varepsilon_{\mathrm{Nd}}$ and $T_{\mathrm{DM}}$ values with significant geochemical parameters, element concentrations or elemental ratios (e.g. the Porcia metaluminous quartz-diorite, sample PORJ-9 and the Ancares peraluminous leuco- granite, sample DJ-277 have very similar $\varepsilon_{\mathrm{Nd}(\mathrm{i})}$ and $T_{\mathrm{DM}}$ values). Furthermore, $T_{\mathrm{DM}}$ values in granitoids are very similar to those reported in coeval mafic rocks in the IVB ( Morenoventas et al., 1995; Bea et al., 2006; Orejana et al., 2009). In the studied granitoids (Table 2) the $T_{\mathrm{DM}}$ values overlap those of the mafic rocks analysed by the above authors ( $T_{\mathrm{DM}}$ ca. 0.94 to $1.35 \mathrm{Ga}$ ). Moreover, a similar range in $T_{\mathrm{DM}}$ values is found in pre-Variscan (Ediacaran to Ordovician) mafic rocks and granitoids (Fernandez-Suarez et al., 1998; Murphy et al., 2008; Sanchez-Garcia et al., 2010).

\section{Inherited zircon ages}

In addition to recording crystallization ages, zircons analyzed from the lateVariscan granitoids may preserve evidence of the age of their source rocks as well as the assimilation of country rocks during magma ascent and emplacement.

It should be stated that owing to the small size of the zircons analysed in the selected samples and the technique utilized (LA-ICP- MS) the U-Pb data reported in Table 3 correspond to zircons whose size was large enough to accommodate an analysis. Therefore these results should be taken with some caution although we are confident that the number of grains analysed (Table 3) and the fact that only 3 zircons with pre- Late Neoproterozoic (discordant) ages were found (Table 3) grant the discussion that follows. Of the 20 samples investigated for this study, xenocrystic zircon was found only in 11 granitoids. Table 3 shows the results of the $\mathrm{U}-\mathrm{Pb}$ analyses carried out in such xenocrysts. The table contains 57 concordant analyses out of an initial set of 81 analyses of which 21 (younger than $650 \mathrm{Ma}$ ) were rejected because of high discordance. As discordance in LA-ICP-MS analyses can be caused by any combination of i) lead loss, ii) analyses of mixed aged domains, iii) high common $\mathrm{Pb}$; we consider that those analyses should not be used in further discussions as corrections or assumptions do not warrant that the interpreted age is correct. In this table we also show the isotopic ratios and ages of three analyses corresponding to the only three zircons that yielded discordant ages older than 650 Ma.

The 57 concordant zircon analyses, whose isotopic ratios and derived ages are given in Table 3 and shown in a Wetherill Concordia plot in Fig. 7, have ages ranging from 458 to $676 \mathrm{Ma}$, with $90 \%$ of data comprised between 490 and $646 \mathrm{Ma}$, corresponding to Neoproter- ozoic (mostly Ediacaran), Cambrian and Ordovician ages. Only three highly discordant analyses (Table 3) yielded ages older than $650 \mathrm{Ma}$. The data suggest that most of the inherited zircons in late-Variscan granitoids of the IVB have been ultimately originated in zircon- forming events between 650 and 490 Ma, i.e. mostly within the time span of the Cadomian orogeny and the initial rifting that led to the opening of the Rheic Ocean in the northern margin of Gondwana (Murphy et al., 2006; Linnemann et al., 2008; Nance et al., 2008; Nance et al., 2010).

\section{Discussion}

Taken together, our data allow an assessment of the relationship between the $\mathrm{Sm}-\mathrm{Nd}$ isotopic signature and the age and possible nature of crustal sources in post-collisional granitoid rock.

\subsection{Neodymium isotopes}

The granitoid with the highest $T_{\mathrm{DM}}$ value (Villavieja de Yeltes, sample LD-6) also has the highest apparent amount of xenocrystic zircon (Table 3) suggesting that higher zircon inheritance represents a higher degree of crustal assimilation and/or restite entrainment. In this regard it is noteworthy that in a detailed study of spinel-bearing inclusions of metasedimentary origin in lateVariscan granitoids and mafic rocks from the Cantabrian Zone, Suarez et al. (1992) found ample evidence for crustal assimilation at temperatures in excess of $800{ }^{\circ} \mathrm{C}$ in many of these intrusions. Samples PORJ-9 (Porcia Pluton), SALJ-2, 4 (Salave Pluton) with high $T_{\mathrm{DM}}$ values $(1.37-1.52 \mathrm{Ga})$ represent two of the intrusions reported by Suarez et al. (1992) to contain a high amount of spinel-bearing inclusions. Unfortunately no data on xenocrystic zircon content are available for these plutons. Samples from the Linares and Arcellana plutons (LD-2 and LD-4) have lower $T_{\mathrm{DM}}$ values (1.28 and 1.24 Ga respectively) than the Porcia and Salave samples (Suarez et al., 1992) and also contain lesser amounts of restitic (metasedimentary) inclusions. In this study, only one zircon ( $574 \pm 15 \mathrm{Ma}$ ) xenocryst was analysed in the Linares pluton (Table 3). A study by (Klotzli et al., 2001) reports inherited lower crustal mineral assemblages (granulitized mangerites) in Variscan granites from the South Bohemian Batholith. Zircons separated from these inclusions yielded dominant Cadomian ages (590-500 Ma) with an age peak similar to that found in this study (Fig. 7).

Zircons from the Ancares and Tojiza plutons (samples DJ-277 and TOJ-5 with high $T_{\mathrm{DM}}$ values of 1.48 and $1.51 \mathrm{Ga}$ respectively) were not analysed in this study but Fernandez-Suarez et al. (2000a) found a significant amount of inherited zircon component in a U-Pb ID-TIMS study of zircons from those same samples.

Conversely, both mafic rocks and granitoids that appear to have a lesser degree of crustal contamination have lower $T_{\mathrm{DM}}$ values defining a relatively narrow range between ca. 0.95 and $1.2 \mathrm{Ga}$. This is also shown in a recent study by (Orejana et al., 2009) in which geochemically primitive gabbroic rocks of the Spanish Central System (Central Iberian Zone) have $T_{\mathrm{DM}}$ values in the range 0.9-1.1 Ga. This range is also typical of pre-Variscan igneous rocks as shown by the data of Sanchez-Garcia et al. (2008) for Cambrian (ca. $520 \mathrm{Ma}$ ) mafic rocks, Montero et al. (2009) for Ordovician (ca. $480 \mathrm{Ma}$ ) peralkaline granites, Murphy et al. (2008) for Ordovician volcanics (ca.460 Ma) and by FernandezSuarez et al. (1998) for Ediacaran (ca. $600 \mathrm{Ma}$ ) I-type calc-alkaline granitoids in northern Spain, and Castro et al. (2003) for early Variscan (ca. $345 \mathrm{Ma}$ ) mafic rocks.

Within our data set, those granitoids that show limited evidence for crustal contamination and in which no inherited zircons were detected in this study (e.g. Neira, Caldas de Reis, Merida plutons) have $T_{\mathrm{DM}}$ b 1.2 and are within the $T_{\mathrm{DM}}$ range $(0.9-1.1 \mathrm{Ga})$ of the putatively primitive and uncontaminated mantle derived mafic rocks reported by Orejana et al. (2009). The geochemistry of these granitoids also matches the main geochemical features of infracrustal (I-, $I P$-type) granitoids of Villaseca et al. (1998, 2009).

There is a remarkable match between the range of $T_{\mathrm{DM}}$ values in lateVariscan granitoids and the range of $T_{\mathrm{DM}}$ values in lower crustal metaigneous xenoliths of the Spanish Central System (1.05 to

$1.53 \mathrm{Ga}$ ) reported in (Villaseca et al., 1999). The $T_{\mathrm{DM}}$ range in these metaigneous xenoliths (extending to values higher than $1.2 \mathrm{Ga}$ ) could reflect processes of crustal contamination during the magmatic history of the protoliths in the same manner as observed in the late-Variscan granitoids and mafic rocks.

The above analysis indicates that not even the most primitive and uncontaminated mafic rocks have Nd isotopic compositions that match that of the depleted mantle at the time of formation (see Table 2, and also Murphy et al., 2008; Orejana et al., 2009). Therefore we argue that the lineage of most crustal igneous components in Iberia can be traced to a subcontinental lithospheric mantle enriched between ca. 0.9 and $1.1 \mathrm{Ga}$ (Murphy et al., 2008). 
Table 1

Major, trace and REE composition of selected granitoids.

\begin{tabular}{|c|c|c|c|c|c|c|c|c|c|c|c|c|c|c|c|c|c|c|}
\hline Sample & Pluton & Rock type & $\mathrm{SiO} 2$ & $\mathrm{TiO} 2$ & $\mathrm{Al} 2 \mathrm{O} 3$ & $\mathrm{FeO}(\mathrm{t})$ & $\mathrm{MnO}$ & $\mathrm{MgO}$ & $\mathrm{CaO}$ & $\mathrm{Na} 2 \mathrm{O}$ & $\mathrm{K} 2 \mathrm{O}$ & P2O5 & $\begin{array}{l}\text { A/CNK } \\
\text { (molar) }\end{array}$ & $\mathrm{Rb}$ & $\mathrm{Sr}$ & $\mathrm{Ba}$ & $\mathrm{Y}$ & $\mathrm{Zr}$ \\
\hline SALJ-2 & Salave & Qtz-diorite & 55.81 & 1.29 & 16.14 & 8.45 & 0.14 & 6.57 & 6.61 & 2.37 & 2.31 & 0.31 & 0.88 & 61.4 & 433.9 & 658.0 & 25.60 & 172.30 \\
\hline SALJ-4 & Salave & $\begin{array}{l}\text { Amph-Bt } \\
\text { Granodiorite }\end{array}$ & 63.24 & 1.05 & 16.81 & 6.72 & 0.11 & 1.53 & 4.39 & 3.61 & 2.33 & 0.21 & 1.02 & 70.5 & 686.4 & 1337.0 & 17.40 & 248.30 \\
\hline PORJ-9 & Porcia & Qtz-diorite & 54.61 & 1.26 & 18.25 & 7.32 & 0.11 & 6.00 & 8.08 & 2.50 & 1.55 & 0.31 & 0.89 & 42.7 & 546.6 & 581.0 & 17.00 & 156.60 \\
\hline DJ-29 & Boal & $\begin{array}{l}\text { Bt-Ms } \\
\text { Monzogranite }\end{array}$ & 72.57 & 0.27 & 15.41 & 1.66 & 0.04 & 0.76 & 1.66 & 4.55 & 2.96 & 0.12 & 1.12 & 112.8 & 234.9 & 255.0 & 5.73 & 98.94 \\
\hline DJ-277 & Ancares & Bt-Ms Leucogranite & 74.63 & 0.15 & 14.08 & 1.21 & 0.06 & 0.33 & 1.00 & 3.64 & 4.77 & 0.14 & 1.10 & 282.5 & 76.5 & 256.3 & 10.48 & 52.83 \\
\hline TOJ-5 & Tojiza & $\begin{array}{l}\text { Amph-Bt } \\
\text { Granodiorite }\end{array}$ & 65.73 & 0.50 & 17.75 & 3.47 & 0.05 & 1.08 & 3.25 & 2.69 & 5.32 & 0.17 & 1.10 & 90.8 & 223.5 & 2636.0 & 15.80 & 301.80 \\
\hline CV-1 & C. Verde & $\begin{array}{l}\text { Amph-Bt } \\
\text { Granodiorite }\end{array}$ & 67.05 & 0.58 & 15.90 & 4.01 & 0.08 & 1.74 & 3.03 & 2.91 & 4.52 & 0.18 & 1.05 & 160.2 & 204.6 & 609.0 & 23.60 & 170.00 \\
\hline NE-3 (E) & Neira & $\begin{array}{l}\text { Microgranular } \\
\text { enclave }\end{array}$ & 60.25 & 1.03 & 17.41 & 6.52 & 0.11 & 2.45 & 4.86 & 3.89 & 3.07 & 0.41 & 0.94 & 108.3 & 258.2 & 730.0 & 44.80 & 408.00 \\
\hline NE-4 & Neira & $\begin{array}{l}\text { Amph-Bt } \\
\text { Granodiorite }\end{array}$ & 64.87 & 0.80 & 16.35 & 4.97 & 0.08 & 1.98 & 3.05 & 3.35 & 4.25 & 0.28 & 1.04 & 132.7 & 188.5 & 771.0 & 24.40 & 312.30 \\
\hline VIV-7 & S.Ciprian & $\begin{array}{l}\text { Bt-Ms } \\
\text { Monzogranite }\end{array}$ & 70.94 & 0.25 & 16.69 & 1.43 & 0.03 & 0.72 & 1.12 & 3.25 & 5.39 & 0.17 & 1.26 & 277.2 & 89.3 & 417.0 & 14.90 & 141.60 \\
\hline LD-1 & Ponferrada & $\begin{array}{l}\text { Bt-Ms } \\
\text { Monzogranite }\end{array}$ & 71.25 & 0.29 & 15.32 & 1.50 & 0.06 & 0.49 & 0.93 & 2.86 & 5.57 & 0.18 & 1.23 & 284.5 & 102.2 & & & \\
\hline LD-2 & Linares & Bt Granodiorite & 68.29 & 0.52 & 15.35 & 2.79 & 0.06 & 1.17 & 2.36 & 3.33 & 4.22 & 0.17 & 1.07 & 213.0 & 217.6 & 602.7 & 23.57 & 202.73 \\
\hline LD-3 & Arcellana & $\begin{array}{l}\text { Amph-Bt } \\
\text { Granodiorite }\end{array}$ & 63.81 & 0.71 & 16.6 & 3.86 & 0.09 & 2.19 & 3.84 & 3.19 & 3.66 & 0.18 & 1.03 & 130.9 & 312.6 & & & \\
\hline LD-4 & Carlés & $\begin{array}{l}\text { Amph-Bt } \\
\text { Granodiorite }\end{array}$ & 67.18 & 0.54 & 15.79 & 2.86 & 0.06 & 1.52 & 2.84 & 3.11 & 4.19 & 0.14 & 1.07 & 145.5 & 267.0 & 785.5 & 29.57 & 186.11 \\
\hline LD-5 & La Alberca & $\begin{array}{l}\text { Amph-Bt } \\
\text { Granodiorite }\end{array}$ & 66.74 & 0.62 & 15.77 & 3.34 & 0.07 & 1.45 & 1.74 & 3.32 & 4.47 & 0.32 & 1.17 & 226.0 & 164.3 & & & \\
\hline LD-6 & $\begin{array}{l}\text { Villavieja de } \\
\text { Yeltes }\end{array}$ & $\begin{array}{l}\text { Bt-Ms } \\
\text { Monzogranite }\end{array}$ & 72.99 & 0.28 & 14.51 & 1.42 & 0.05 & 0.46 & 0.76 & 3.56 & 4.41 & 0.32 & 1.21 & 306.7 & 40.6 & 195.3 & 13.35 & 104.57 \\
\hline LD-7 & Cipérez & $\begin{array}{l}\text { Bt-Ms } \\
\text { Monzogranite }\end{array}$ & 70.88 & 0.36 & 14.9 & 1.95 & 0.06 & 0.57 & 0.8 & 3.18 & 4.72 & 0.33 & 1.26 & 318.9 & 51.4 & & & \\
\hline LD-8 & Trujillo & $\begin{array}{l}\text { Bt-Ms } \\
\text { Monzogranite }\end{array}$ & 73.01 & 0.23 & 14.83 & 1.09 & 0.03 & 0.34 & 0.6 & 4.17 & 4.06 & 0.54 & 1.20 & 383.5 & 33.6 & 118.2 & 6.25 & 64.55 \\
\hline LD-9 & Mérida & $\begin{array}{l}\text { Bt-Ms } \\
\text { Monzogranite }\end{array}$ & 73.52 & 0.27 & 13.85 & 1.68 & 0.05 & 0.35 & 0.76 & 3.58 & 4.7 & 0.13 & 1.12 & 360.3 & 40.9 & 194.3 & 39.18 & 167.11 \\
\hline LD-10 & Alburquerque & $\begin{array}{l}\text { Bt-Ms } \\
\text { Monzogranite }\end{array}$ & 72.01 & 0.27 & 14.72 & 1.49 & 0.04 & 0.42 & 0.81 & 3.69 & 5.12 & 0.37 & 1.12 & 309.9 & 38.2 & & & \\
\hline LD-11 & Cabeza de Araya & $\begin{array}{l}\text { Bt-Ms } \\
\text { Monzogranite }\end{array}$ & 72.17 & 0.35 & 14.27 & 1.85 & 0.04 & 0.63 & 0.67 & 3.29 & 4.92 & 0.31 & 1.19 & 187.8 & 44.9 & & & \\
\hline LD-14 & Veiga & $\begin{array}{l}\text { Bt-Ms } \\
\text { Monzogranite }\end{array}$ & 70.16 & 0.42 & 14.82 & 2.31 & 0.06 & 0.87 & 1.94 & 3.3 & 4.56 & 0.22 & 1.07 & 184.7 & 149.0 & & & \\
\hline LD-15 & Orense & $\begin{array}{l}\text { Bt-Ms } \\
\text { Monzogranite }\end{array}$ & 73.17 & 0.25 & 14.24 & 1.37 & 0.06 & 0.39 & 0.74 & 3.82 & 4.74 & 0.1 & 1.12 & 316.5 & 44.0 & 279.0 & 29.14 & 123.05 \\
\hline LD-16 & Traba & Bt-Ms Leucogranite & 75.19 & 0.17 & 13.27 & 1.03 & 0.04 & 0.26 & 0.54 & 3.88 & 4.7 & 0.03 & 1.07 & 349.4 & 22.0 & 118.7 & 63.62 & 112.54 \\
\hline LD-17 & Caldas de Reis & $\begin{array}{l}\text { Amph-Bt } \\
\text { Granodiorite }\end{array}$ & 66.31 & 0.53 & 16.04 & 3.35 & 0.08 & 0.63 & 2.4 & 3.99 & 5.13 & 0.2 & 0.97 & 180.7 & 144.2 & 929.6 & 33.53 & 432.12 \\
\hline LD-18 & Braga & $\begin{array}{l}\text { Amph-Bt } \\
\text { Granodiorite }\end{array}$ & 65.74 & 0.91 & 15.77 & 3.64 & 0.07 & 1.33 & 2.18 & 3.09 & 5.32 & 0.47 & 1.06 & 268.7 & 251.4 & 1125.4 & 22.81 & 325.71 \\
\hline LD-19 & Guarda & $\begin{array}{l}\text { Bt-Ms } \\
\text { Monzogranite }\end{array}$ & 70.55 & 0.45 & 14.88 & 2.60 & 0.07 & 0.75 & 0.68 & 2.8 & 5.03 & 0.29 & 1.32 & 320.6 & 63.0 & & & \\
\hline LD-20 & El Álamo & Gabbro & 46.11 & 0.73 & 12.63 & 11.38 & 0.18 & 17.24 & 5.46 & 1.77 & 0.78 & 0.18 & 0.92 & 30.5 & 245.8 & 228.4 & 11.84 & 116.93 \\
\hline LD-21 & El Mirón & $\begin{array}{l}\text { Amph-Bt } \\
\text { Granodiorite }\end{array}$ & 66.22 & 0.66 & 15.89 & 3.53 & 0.05 & 1.44 & 2.71 & 3.63 & 4.01 & 0.34 & 1.04 & 174.7 & 163.2 & & & \\
\hline
\end{tabular}

Major elements in wt.\% oxide and trace elements in parts per million. Reported volatile free. See text for discussion of techniques and associated errors.

Granitoids and mafic rocks with $T_{\mathrm{DM}}$ values significantly in excess of ca. $1 \mathrm{Ga}$ may reflect varying degrees of contamination with metasedimentary crustal components. An alternative scenario that produced high $T_{\mathrm{DM}}$ values by different degrees of mixing of Variscan depleted mantle melts with varying proportions of Neoproterozoic, Paleoproterozoic or Archaean (metasedimentary + metaigneous) crust is unlikely as it would probably have produced a much wider range of $T_{\mathrm{DM}}$ values. Moreover, as the same range of $T_{\mathrm{DM}}$ values occurs in early Palaeozoic and Neoproterozoic granitoids and mafic rocks, the most likely explanation is that the $T_{\mathrm{DM}}$ values reflect extraction from a mantle enriched around $1 \mathrm{Ga}$. An alternative scenario in which mixtures of contemporaneous depleted mantle and crust occurred in the same proportions so as to yield the same narrow range of $T_{\mathrm{DM}}$ values in mafic rocks and I-type granitoids in tectonothermal events ranging from ca. 600 to 300 Ma is considered highly unlikely.

Our view is therefore that mafic rocks in the IVB derive from a ca.

0.9 to $1.1 \mathrm{Ga}$ isotopically enriched and geochemically heterogeneous subcontinental lithospheric mantle (SCLM) (Murphy et al., 2008) and the granitoids (including the late-Variscan suite) are derived from crustal (igneous) protoliths whose ultimate source is the same SCLM, as reflected in their narrow range of $T_{\mathrm{DM}}$ values (ca. 0.95-1.2 Ga). Higher $T_{\mathrm{DM}}$ values are attributed to significant crustal assimilation of metasedimentary protoliths with a different time-integrated $\mathrm{Sm} / \mathrm{Nd}$. An argument in favour of the above can be found in the work of Bea et al. (2007) and Montero et al. (2007) who studied the Ordovician (ca. 495-480 Ma) volcanic and plutonic rocks of the Ollo de Sapo domain in Central Spain (CIZ). These authors found that the Ollo de 


\begin{tabular}{|c|c|c|c|c|c|c|c|c|c|c|c|c|c|c|c|c|c|c|c|}
\hline $\mathrm{Nb}$ & $\mathrm{Hf}$ & $\mathrm{Ta}$ & $\mathrm{Pb}$ & Th & $\mathrm{U}$ & $\mathrm{La}$ & $\mathrm{Ce}$ & $\operatorname{Pr}$ & $\mathrm{Nd}$ & $\mathrm{Sm}$ & $\mathrm{Eu}$ & Gd & $\mathrm{Tb}$ & Dy & Ho & $\mathrm{Er}$ & $\mathrm{Tm}$ & $\mathrm{Yb}$ & $\mathrm{Lu}$ \\
\hline 13.20 & 2.37 & 0.82 & 11.72 & 7.00 & 1.40 & 26.30 & 54.20 & 6.58 & 26.30 & 5.65 & 1.60 & 5.34 & 0.80 & 4.99 & 1.01 & 2.89 & 0.42 & 2.59 & 0.40 \\
\hline 16.60 & 3.30 & 1.17 & 34.00 & 13.18 & 1.96 & 44.8 & 84.90 & 9.85 & 36.0 & 6.83 & 1.53 & 5.53 & 0.79 & 4.47 & 0.84 & 2.27 & 0.31 & 2.02 & 0.28 \\
\hline 12.30 & 1.48 & 0.83 & 7.41 & 6.47 & 1.14 & 27.80 & 54.2 & 6.33 & 24.1 & 4.75 & 1.86 & 3.97 & 0.57 & 3.34 & 0.66 & 1.77 & 0.25 & 1.60 & 0.24 \\
\hline 7.58 & 1.66 & 1.46 & 17.08 & 6.39 & 2.38 & 11.7 & 25.1 & 2.75 & 9.87 & 2.02 & 0.45 & 1.55 & 0.23 & 1.24 & 0.22 & 0.59 & 0.10 & 0.57 & 0.09 \\
\hline 14.10 & 1.20 & 3.11 & 17.61 & 8.35 & 2.65 & 14.4 & 33.8 & 3.70 & 13.3 & 3.16 & 0.43 & 2.51 & 0.33 & 2.07 & 0.38 & 0.99 & 0.16 & 0.98 & 0.14 \\
\hline 8.60 & 0.95 & 0.50 & 23.00 & 7.33 & 0.94 & 34.2 & 62.0 & 6.94 & 26.5 & 4.80 & 2.14 & 3.95 & 0.51 & 3.18 & 0.67 & 1.97 & 0.26 & 1.63 & 0.24 \\
\hline 12.50 & 2.29 & 1.36 & 22.94 & 17.06 & 4.78 & 39.0 & 80.3 & 9.22 & 34.20 & 6.66 & 1.19 & 5.52 & 0.83 & 4.83 & 0.93 & 2.66 & 0.36 & 2.46 & 0.36 \\
\hline 23.00 & 2.54 & 1.58 & 15.95 & 9.11 & 2.92 & 35.5 & 82.4 & 10.8 & 45.5 & 10.5 & 2.17 & 10.1 & 1.52 & 9.14 & 1.77 & 4.90 & 0.67 & 4.01 & 0.58 \\
\hline 20.10 & 2.89 & 1.30 & 18.00 & 13.20 & 3.01 & 43.2 & 90.7 & 10.7 & 39.8 & 7.75 & 1.74 & 6.55 & 0.94 & 5.22 & 0.98 & 2.70 & 0.36 & 2.21 & 0.32 \\
\hline \multirow[t]{2}{*}{17.00} & 4.08 & 2.18 & 32.63 & 22.60 & 10.09 & 34.8 & 73.3 & 8.35 & 29.4 & 5.99 & 0.67 & 4.34 & 0.58 & 2.85 & 0.48 & 1.22 & 0.17 & 1.10 & 0.16 \\
\hline & & & 31.20 & 14.80 & & & & & & & & & & & & & & & \\
\hline \multirow[t]{2}{*}{14.03} & 4.76 & 0.83 & 18.90 & 16.70 & 0.72 & 29.01 & 61.70 & 6.45 & 24.16 & 4.88 & 0.99 & 4.55 & 15.01 & 4.34 & 0.83 & 2.22 & 0.39 & 2.35 & 0.34 \\
\hline & & & 25.10 & 19.60 & & & & & & & & & & & & & & & \\
\hline \multirow[t]{2}{*}{17.70} & 4.89 & 0.90 & 21.60 & 23.10 & 0.94 & 48.57 & 93.50 & 10.72 & 39.66 & 7.03 & 1.04 & 6.21 & 21.40 & 5.70 & 1.12 & 3.24 & 0.51 & 2.93 & 0.43 \\
\hline & & & 25.50 & 18.50 & & & & & & & & & & & & & & & \\
\hline \multirow[t]{2}{*}{18.58} & 2.72 & 1.81 & 25.60 & 18.50 & 0.57 & 19.13 & 40.74 & 5.07 & 19.46 & 4.15 & 0.28 & 3.98 & 11.47 & 3.02 & 0.48 & 1.18 & 0.20 & 1.14 & 0.17 \\
\hline & & & 28.20 & 23.20 & & & & & & & & & & & & & & & \\
\hline 8.11 & 1.69 & 1.48 & 22.30 & 10.10 & 0.26 & 8.59 & 18.72 & 2.44 & 8.88 & 2.02 & 0.22 & 1.58 & 5.10 & 1.28 & 0.24 & 0.51 & 0.09 & 0.64 & 0.07 \\
\hline \multirow[t]{4}{*}{21.57} & 3.64 & 1.88 & 34.00 & 27.40 & 1.14 & 31.42 & 68.27 & 8.06 & 29.61 & 6.81 & 0.44 & 6.47 & 21.05 & 7.19 & 1.47 & 4.31 & 0.69 & 4.77 & 0.63 \\
\hline & & & 23.20 & 15.90 & & & & & & & & & & & & & & & \\
\hline & & & 28.50 & 12.00 & & & & & & & & & & & & & & & \\
\hline & & & 34.10 & 15.40 & & & & & & & & & & & & & & & \\
\hline 13.80 & 3.16 & 1.71 & 35.10 & 22.80 & 0.85 & 20.77 & 44.68 & 5.55 & 21.64 & 4.74 & 0.54 & 4.91 & 14.44 & 5.34 & 1.07 & 3.07 & 0.53 & 3.53 & 0.56 \\
\hline 27.93 & 4.72 & 2.66 & 51.90 & 31.70 & 1.44 & 11.14 & 25.70 & 3.61 & 14.87 & 4.97 & 0.23 & 7.13 & 21.65 & 10.74 & 2.31 & 6.74 & 1.10 & 7.54 & 1.07 \\
\hline 25.18 & 8.36 & 1.13 & 31.70 & 21.40 & 1.23 & 49.34 & 101.98 & 12.06 & 45.23 & 8.71 & 1.57 & 7.94 & 14.72 & 7.06 & 1.31 & 3.75 & 0.54 & 3.46 & 0.54 \\
\hline \multirow[t]{2}{*}{24.65} & 7.22 & 0.95 & 35.70 & 42.10 & 1.08 & 81.54 & 169.04 & 20.51 & 77.39 & 12.08 & 1.58 & 8.17 & 41.18 & 5.30 & 0.92 & 2.33 & 0.33 & 1.94 & 0.29 \\
\hline & & & 24.00 & 21.60 & & & & & & & & & & & & & & & \\
\hline \multirow[t]{2}{*}{7.01} & 2.22 & 0.20 & 1.60 & 2.80 & 0.41 & 13.00 & 27.45 & 3.41 & 13.76 & 2.72 & 0.84 & 2.81 & 2.64 & 2.55 & 0.49 & 1.48 & 0.19 & 1.24 & 0.18 \\
\hline & & & 31.00 & 24.00 & & & & & & & & & & & & & & & \\
\hline
\end{tabular}

Sapo igneous rocks contain an unusually high proportion of inherited zircon (e.g. most samples contain a zircon population in which over $60-70 \%$ of imaged grains contain inherited cores). The $T_{\mathrm{DM}}$ values for representative samples reported by these authors are mostly higher than $1.6 \mathrm{Ga}$. In sum, we consider that the apparent narrow range of $T_{\mathrm{DM}}$ values found in mafic rocks and granitoids that have experienced limited crustal (metasedimentary) assimilation is geologically signif- icant and points to the primordial origin of the Iberian lower crust in (or after) latest Mesoproterozoic-earliest Neoproterozoic times.

\subsection{Zircon inheritance}

Although some pre-Ediacaran zircons were found in our study, signaling the presence of pre- late-Neoproterozoic populations, most inherited zircons dated in the late-Variscan granitoids are not older than ca. 650 Ma (Table 3) and they can be considered to have been formed mostly during events related to the Cadomian arc-building orogeny in northern Gondwana (Nance et al., 2008; Nance et al., 2010). A geochronological U-Pb study of zircons from lower crustal granulite xenoliths from the Spanish Central System (Central Iberian Zone) (Fernandez-Suarez et al., 2006) also failed to detect any zircon older than ca. $600 \mathrm{Ma}$ and found a range of inherited zircon ages similar to those of inherited zircon in the granitoids studied herein. In addition, the "granulitic" zircons in these xenoliths yielded ages between ca. 308 and 285 $\mathrm{Ma}$, an age range remarkably similar to that of late-Variscan granitoids.

Studies of zircon inheritance in pre-Variscan (Ordovician) igneous rocks have shown the existence of a subordinate but significant 
Table 2

Sm-Nd isotope data.

\begin{tabular}{|c|c|c|c|c|c|c|c|c|c|}
\hline Pluton & Sample & $\mathrm{Nd}(\mathrm{ppm})$ & $\mathrm{Sm}(\mathrm{ppm})$ & ${ }^{147} \mathrm{Sm} /{ }^{144} \mathrm{Nd}$ & ${ }^{143} \mathrm{Nd} /{ }^{144} \mathrm{Nd}$ & $2 \sigma$ & Epsilon (0) & Epsilon (300) & $T_{\mathrm{DM}}$ \\
\hline Cantabrian Zone & & & & & & & & & $(\mathrm{Ma})$ \\
\hline Linares & LD 2 & 23.22 & 4.88 & 0.13 & 0.51 & 5 & -6.3 & -3.6 & 1284 \\
\hline Arcellana & $\mathrm{LD} 4$ & 40.66 & 7.64 & 0.11 & 0.51 & 8 & -7.9 & -4.6 & 1236 \\
\hline \multicolumn{10}{|c|}{ West Asturian Leonese Zone } \\
\hline Salave & SALJ-2 & 26.3 & 5.65 & 0.13 & 0.51 & 6 & -6.7 & -4.1 & 1373 \\
\hline Salave & SALJ-4 & 36 & 6.83 & 0.13 & 0.51 & 5 & -8.1 & -5.5 & 1495 \\
\hline Porcia & PORJ-9 & 24.1 & 4.75 & 0.13 & 0.51 & 8 & -8.3 & -5.8 & 1516 \\
\hline Boal & DJ-29 & 9.87 & 2.02 & 0.13 & 0.51 & 6 & -4.4 & -1.9 & 1182 \\
\hline Ancares & DJ-277 & 13.3 & 3.16 & 0.13 & 0.51 & 7 & -7.9 & -5.3 & 1483 \\
\hline Tojiza & TOJ-5 & 26.5 & 4.8 & 0.13 & 0,512220 & 8 & -8.2 & -5.6 & 1510 \\
\hline C. Verde & $\mathrm{CV}-1$ & 34.2 & 6.66 & 0.13 & 0.51 & 8 & -7.7 & -5.2 & 1471 \\
\hline Neira & NE-3 (E) & 45.5 & 10.5 & 0.13 & 0.51 & 7 & -2.7 & -0.2 & 1044 \\
\hline Neira & NE-4 & 39.8 & 7.75 & 0.13 & 0.51 & 6 & -4.1 & -1.6 & 1165 \\
\hline S.Ciprian & VIV-7 & 29.4 & 5.99 & 0.13 & 0.51 & 9 & -5.5 & -3.0 & 1285 \\
\hline \multicolumn{10}{|l|}{ Central Iberian Zone } \\
\hline Villavieja de Yeltes & LD 6 & 20.28 & 4.77 & 0.14 & 0.51 & 12 & -6.8 & -4.7 & 1576 \\
\hline Trujillo & LD 8 & 10.04 & 2.24 & 0.1350 & 0.51 & 5 & -5.3 & -2.9 & 1307 \\
\hline Mérida & LD 9 & 30.52 & 6.95 & 0.14 & 0.51 & 5 & -3.2 & -0.9 & 1155 \\
\hline Orense & LD 15 & 21.53 & 5.270 & 0.1480 & 0.51 & 6 & -3.7 & -1.8 & 1372 \\
\hline Traba & $\mathrm{LD} 16$ & 16.11 & 5.57 & 0.21 & 0.51 & 6 & -0.4 & -0.9 & - \\
\hline Caldas de Rei & LD 17 & 45.04 & 8.96 & 0.12 & 0.51 & 8 & -3.9 & -0.9 & 1012 \\
\hline Braga & LD 18 & 76.42 & 12.37 & 0.1 & 0.51 & 7 & -9.8 & -5.9 & 1200 \\
\hline
\end{tabular}

population of zircon older than ca. 650 Ma (Fernandez-Suarez et al., 1999; Zeck et al., 2004; Bea et al., 2007; Solá et al., 2008), although the dominant population is younger than ca. $650 \mathrm{Ma}$.

Similar, older-than-650 Ma zircon, is found in S-type anatectic Variscan granites (Castineiras et al., 2008; Pereira et al., 2008).

Late Neoproterozoic and Paleozoic sedimentary rocks from NW Iberia contain a significant population of detrital zircon in the age ranges ca. 0.65-1.1 Ga, 1.8-2.2 Ga and also in some instances a significant amount of Archaean (ca. 2.5-3.2 Ga) zircons (Nance et al., 2008 and references therein). The relative abundance of these "older" detrital zircon populations is much higher in these sedimentary rocks than in the inherited zircon population of any granitoid (Variscan or pre-Variscan) studied so far. In the early Paleozoic sedimentary rocks the proportion of pre-650 Ma zircons can be as high as ca. 70\% (Fernandez-Suarez et al., 2000b; Gutierrez-Alonso et al., 2003; Martinez Catalan et al., 2004) whereas, for example, the proportion of such zircons in the inherited population of Ordovician igneous rocks in the Ollo de Sapo domain (which contain an unusually high proportion of inherited zircon) is less than $35 \%$. And as stated above, the proportion of these older populations is even much more attenuated in the inherited component of late-Variscan granitoids and apparently absent in lower crustal metaigneous granulitic xenoliths.

Many of these Neoproterozoic and pre-Variscan Paleozoic sedimentary rocks have $T_{\mathrm{DM}}$ values mostly ranging from ca. 1.4 to 1.9 Ga (Ugidos et al., 1997; Fernandez-Suarez et al., 1999; Castro et al., 2003.

Therefore granitoids that have assimilated significant amounts of this kind of metasedimentary crust (or were produced by its melting) can be expected to contain a significant proportion of pre-Ediacaran zircons as xenocrysts and to have higher than 1.2 Ga $T_{\mathrm{DM}}$ values (as is the case in some of the Ollo de Sapo igneous rocks with $T_{\mathrm{DM}} \mathrm{N} 1.5 \mathrm{Ga}$ and a significant proportion of pre-650 Ma inherited zircon xenocrysts, (see Montero et al., 2007). However, an apparent contradiction arises here: If the late Variscan granitoids with high $T_{\mathrm{DM}}$ values have assimilated that kind of metasedimentary crust, why are pre-650 inherited zircons apparently absent or at least so scarce? A possible explanation could be that the initial melts (either mantle-derived or derived from metaigneous sources) were contaminated by the lower crustal (granulitic) equivalent of these metasedimentary rocks. These lower crustal metasediments have
$T_{\mathrm{DM}}$ values around 1.7-1-8 Ga ("metapelitic" xenoliths in Villaseca et al., 1999) and do not contain (or contain very little amounts) of pre-650 Ma zircons (Fernandez-Suarez et al., 2006). This idea is consistent with the work of Suarez et al. (1992) on spinel bearing inclusions in late-Variscan granitoids, whose parageneses indicate equilibration with the host magma at temperatures in excess of $800{ }^{\circ} \mathrm{C}$ and relatively high pressures. This would suggest that granitoids acquired their "final" $\mathrm{Nd}$ isotopic signature in the lower crust.

\subsection{General conclusions}

The combined observations on the Nd isotopic signatures of granitoids and their zircon inheritance allow the following main conclusions to be extracted:

The main inherited component in late-Variscan granitoids is represented by a population of xenocrystic zircon with lateNeoproterozoic early-Cambrian ages that roughly correspond to tectonothermal events related to the Cadomian orogeny and early Paleozoic ensialic rifting in northern Gondwana (references above) and these ages coincide with the pre-Variscan ages found in the lower crustal granulite xenoliths (Fernandez-Suarez et al., 2006).

The "Cadomian" s.l. metaigneous basement of Iberia (roughly ca. 640$490 \mathrm{Ma})$ is the most likely source for late-Variscan I-type granitoids. Cadomian igneous protoliths (derived either directly from the ca. 0.9-1.1 Ga SCLM, or through melting of a hypothetical older Neoptoterozoic igneous basement) with little or no crustal (metasedimentary) inheritance would generate, upon melting, granitoids with ca. 1-1.2 Ga $T_{\mathrm{DM}}$ values. Contamination of these granitoid magmas with metasedimentary components having high $T_{\mathrm{DM}}$ values would generate granitoids with $T_{\mathrm{DM}}$ values well in excess of $1.2 \mathrm{Ga}$.

The apparent dwindling of the pre-Cadomian inherited zircon component through time might indicate that the pre-650 Ma zircon hosted in lower crustal rocks was recycled by melting during the evolution of the Cadomian magmatic arc and the "Ollo de Sapo" voluminous magmatic event. As a result, in late-variscan times, only a fraction of that zircon was available in the lower crust that melted to produce the late-variscan I-type granitoids. The apparent scarcity of pre-Cadomian zircons in late-Variscan Itype granitoids and lower crustal xenoliths could be the end result of a process whereby pre- 


\begin{tabular}{|c|c|c|c|c|c|c|c|c|c|c|c|c|c|c|c|c|c|}
\hline \multirow[b]{2}{*}{ Anal.\# } & \multirow[b]{2}{*}{$\begin{array}{l}\text { Sample } \\
\text { (pluton) }\end{array}$} & \multirow[b]{2}{*}{$\begin{array}{l}\text { i.s. } \\
{[\mathrm{s}]}\end{array}$} & \multicolumn{6}{|c|}{ Isotopic ratios and $2 \sigma(\%)$ errors } & \multicolumn{6}{|c|}{ Ages and $2 \sigma$ absolute errors (Ma) } & \multicolumn{3}{|c|}{$\begin{array}{l}\text { Reported age } \\
\quad \text { (see text for details) }\end{array}$} \\
\hline & & & ${ }^{206} \mathrm{~Pb} /{ }^{238} \mathrm{U}$ & $\pm 2 \sigma$ & ${ }^{207} \mathrm{~Pb} /{ }^{235} \mathrm{U}$ & $\pm 2 \sigma$ & ${ }^{207} \mathrm{~Pb} /{ }^{206} \mathrm{P} \quad \mathrm{b}$ & $\pm 2 \sigma$ & ${ }^{206} \mathrm{~Pb} /{ }^{238} \mathrm{U}$ & $\pm 2 \sigma$ & ${ }^{207} \mathrm{~Pb} /{ }^{235} \mathrm{U}$ & $\pm 2 \sigma$ & ${ }^{207} \mathrm{~Pb} /{ }^{206} \mathrm{~Pb}$ & $\pm 2 \sigma$ & $\begin{array}{l}\text { Age } \\
\text { (Ma) }\end{array}$ & $\pm 2 \sigma$ & Disc \% \\
\hline oc14f13 & VV YELTES & 21 & 0.0737 & 1.98 & 0.5682 & 2.46 & 0.0556 & 2.02 & 459 & 9 & 457 & 9 & 434 & 46 & 458 & 8 & -5.8 \\
\hline oc19g15 & ORENSE & 15 & 0.0740 & 1.86 & 0.5899 & 4.72 & 0.0575 & 3.14 & 460 & 8 & 471 & 18 & 508 & 68 & 459 & 8 & 9.4 \\
\hline oc19a15 & RICOBAYO & 19 & 0.0754 & 1.40 & 0.5978 & 2.26 & 0.0569 & 2.22 & 469 & 6 & 476 & 9 & 488 & 48 & 471 & 6 & 3.9 \\
\hline ос20e15 & CALDAS DE REIS & 29 & 0.0763 & 1.76 & 0.5876 & 3.50 & 0.0565 & 3.48 & 474 & 8 & 469 & 13 & 470 & 78 & 473 & 8 & -0.9 \\
\hline oc19a05 & RICOBAYO & 11 & 0.0764 & 2.06 & 0.6182 & 2.32 & 0.0584 & 3.48 & 475 & 9 & 489 & 9 & 544 & 76 & 475 & 9 & 12.7 \\
\hline oc19h09 & TRABA & 12 & 0.0773 & 2.72 & 0.6115 & 4.10 & 0.0576 & 4.18 & 480 & 13 & 484 & 16 & 514 & 92 & 482 & 11 & 6.6 \\
\hline ос15a09 & CIPEREZ & 20 & 0.0782 & 1.30 & 0.6145 & 3.60 & 0.0584 & 2.76 & 486 & 6 & 486 & 14 & 544 & 60 & 485 & 6 & 10.7 \\
\hline ос19a06 & RICOBAYO & 31 & 0.0785 & 1.64 & 0.6267 & 3.16 & 0.0570 & 3.12 & 487 & 8 & 494 & 12 & 488 & 68 & 489 & 7 & 0.2 \\
\hline oc15b07 & CIPEREZ & 11 & 0.0789 & 2.14 & 0.6349 & 2.10 & 0.0576 & 1.92 & 490 & 10 & 499 & 8 & 514 & 42 & 490 & 10 & 4.7 \\
\hline oc15a16 & CIPEREZ & 14 & 0.0794 & 1.60 & 0.6515 & 3.24 & 0.0595 & 3.04 & 493 & 8 & 509 & 13 & 584 & 66 & 493 & 8 & 15.6 \\
\hline oc15a15 & CIPEREZ & 11 & 0.0815 & 2.20 & 0.6316 & 4.66 & 0.0562 & 3.22 & 505 & 11 & 497 & 18 & 460 & 72 & 507 & 10 & -9.8 \\
\hline oc15a14 & CIPEREZ & 17 & 0.0831 & 1.26 & 0.6524 & 4.16 & 0.0584 & 3.06 & 514 & 6 & 510 & 17 & 544 & 68 & 514 & 6 & 5.5 \\
\hline oc19a16 & RICOBAYO & 9 & 0.0833 & 4.60 & 0.7026 & 8.66 & 0.0607 & 6.04 & 516 & 23 & 540 & 36 & 628 & 132 & 516 & 23 & 17.8 \\
\hline oc14f15 & VV YELTES & 9 & 0.0835 & 3.20 & 0.6880 & 3.40 & 0.0596 & 3.02 & 517 & 16 & 532 & 14 & 586 & 66 & 517 & 16 & 11.8 \\
\hline oc15b05 & CIPEREZ & 14 & 0.0835 & 2.02 & 0.6705 & 3.62 & 0.0580 & 2.56 & 517 & 10 & 521 & 15 & 528 & 56 & 517 & 10 & 2.1 \\
\hline oc14g08 & VV YELTES & 52 & 0.0845 & 3.60 & 0.7109 & 6.96 & 0.0597 & 13.32 & 523 & 18 & 545 & 72 & 592 & 288 & 519 & 15 & 11.7 \\
\hline oc15b09 & CIPEREZ & 30 & 0.0849 & 1.76 & 0.6885 & 2.36 & 0.0592 & 2.16 & 525 & 9 & 532 & 10 & 574 & 46 & 528 & 8 & 8.5 \\
\hline oc14f10 & VV YELTES & 21 & 0.0854 & 1.70 & 0.7014 & 2.42 & 0.0595 & 2.56 & 528 & 9 & 540 & 10 & 586 & 56 & 528 & 9 & 9.9 \\
\hline oc15b14 & CIPEREZ & 20 & 0.0853 & 1.52 & 0.7056 & 3.94 & 0.0598 & 3.38 & 528 & 8 & 542 & 17 & 596 & 74 & 528 & 8 & 11.4 \\
\hline oc19b16 & RICOBAYO & 9 & 0.0854 & 2.04 & 0.7138 & 4.72 & 0.0601 & 3.90 & 529 & 10 & 547 & 20 & 606 & 84 & 529 & 10 & 12.7 \\
\hline oc22c12 & VV YELTES & 13 & 0.0859 & 2.02 & 0.6637 & 4.92 & 0.0581 & 3.78 & 531 & 10 & 517 & 20 & 532 & 84 & 531 & 10 & 0.2 \\
\hline oc14g06 & VV YELTES & 24 & 0.0861 & 1.20 & 0.7036 & 1.94 & 0.0591 & 1.68 & 533 & 6 & 541 & 8 & 570 & 36 & 533 & 6 & 6.5 \\
\hline ос21h05 & EL MIRON & 16 & 0.0866 & 1.80 & 0.6977 & 2.50 & 0.0589 & 1.90 & 535 & 9 & 537 & 10 & 562 & 40 & 536 & 9 & 4.8 \\
\hline oc15b15 & CIPEREZ & 15 & 0.0869 & 1.42 & 0.6883 & 3.36 & 0.0580 & 2.38 & 537 & 7 & 532 & 14 & 530 & 52 & 539 & 7 & -1.3 \\
\hline oc14f05 & VV YELTES & 16 & 0.0870 & 1.56 & 0.7159 & 3.86 & 0.0595 & 1.98 & 538 & 8 & 548 & 16 & 584 & 42 & 536 & 8 & 7.9 \\
\hline oc15b10 & CIPEREZ & 24 & 0.0870 & 1.24 & 0.7096 & 2.44 & 0.0590 & 2.64 & 538 & 6 & 544 & 10 & 566 & 58 & 539 & 6 & 4.9 \\
\hline oc14e07 & VV YELTES & 28 & 0.0873 & 1.06 & 0.7105 & 2.26 & 0.0586 & 1.46 & 539 & 5 & 545 & 10 & 552 & 32 & 537 & 5 & 2.4 \\
\hline ос15a06 & CIPEREZ & 20 & 0.0878 & 1.54 & 0.7120 & 2.52 & 0.0591 & 2.38 & 542 & 8 & 546 & 11 & 568 & 52 & 543 & 8 & 4.6 \\
\hline oc22d07 & VV YELTES & 19 & 0.0878 & 2.24 & 0.7265 & 2.98 & 0.0595 & 2.52 & 543 & 12 & 555 & 13 & 584 & 56 & 543 & 12 & 7.0 \\
\hline oc14g13 & VV YELTES & 29 & 0.0884 & 1.56 & 0.7064 & 2.54 & 0.0581 & 2.36 & 546 & 8 & 543 & 11 & 532 & 52 & 545 & 8 & -2.6 \\
\hline oc15a10 & CIPEREZ & 24 & 0.0884 & 1.68 & 0.7417 & 3.86 & 0.0605 & 3.44 & 546 & 9 & 563 & 17 & 620 & 74 & 546 & 9 & 11.9 \\
\hline oc14e10 & VV YELTES & 26 & 0.0887 & 1.20 & 0.7353 & 2.94 & 0.0598 & 2.40 & 548 & 6 & 560 & 13 & 596 & 52 & 548 & 6 & 8.1 \\
\hline oc22c13 & VV YELTES & 17 & 0.0887 & 3.00 & 0.7252 & 3.82 & 0.0599 & 5.18 & 548 & 16 & 554 & 16 & 598 & 112 & 550 & 15 & 8.4 \\
\hline oc14c12 & LA ALBERCA & 18 & 0.0895 & 2.04 & 0.7245 & 6.54 & 0.0595 & 5.08 & 553 & 11 & 553 & 28 & 582 & 110 & 552 & 9 & 5.0 \\
\hline oc15a05 & CIPEREZ & 30 & 0.0896 & 1.20 & 0.7221 & 1.78 & 0.0589 & 1.68 & 553 & 6 & 552 & 8 & 562 & 38 & 553 & 6 & 1.6 \\
\hline ос23a09 & CIPEREZ & 20 & 0.0896 & 1.58 & 0.7284 & 3.26 & 0.0589 & 3.50 & 553 & 8 & 556 & 14 & 562 & 78 & 554 & 8 & 1.6 \\
\hline oc14f06 & VV YELTES & 15 & 0.0898 & 1.44 & 0.7268 & 2.98 & 0.0592 & 2.10 & 555 & 8 & 555 & 13 & 574 & 46 & 554 & 8 & 3.3 \\
\hline oc14e11 & VV YELTES & 42 & 0.0912 & 1.34 & 0.7450 & 2.22 & 0.0588 & 1.32 & 563 & 7 & 565 & 10 & 558 & 28 & 562 & 7 & -0.9 \\
\hline oc14f16 & VV YELTES & 15 & 0.0912 & 1.32 & 0.7480 & 2.68 & 0.0584 & 2.32 & 563 & 7 & 567 & 12 & 542 & 50 & 563 & 7 & -3.9 \\
\hline oc13b12 & LINARES & 13 & 0.0931 & 2.72 & 0.7906 & 2.20 & 0.0617 & 2.50 & 574 & 15 & 592 & 10 & 664 & 54 & 574 & 15 & 13.6 \\
\hline oc19j10 & ORENSE & 23 & 0.0933 & 1.10 & 0.7527 & 2.58 & 0.0590 & 1.74 & 575 & 6 & 570 & 11 & 566 & 38 & 577 & 5 & -1.6 \\
\hline oc14g11 & VV YELTES & 17 & 0.0936 & 1.14 & 0.7852 & 3.76 & 0.0608 & 2.60 & 577 & 6 & 588 & 17 & 630 & 56 & 575 & 6 & 8.4 \\
\hline oc22c14 & VV YELTES & 16 & 0.0945 & 1.58 & 0.7880 & 4.18 & 0.0623 & 2.12 & 582 & 9 & 590 & 19 & 684 & 46 & 581 & 8 & 14.9 \\
\hline oc19b06 & RICOBAYO & 21 & 0.0949 & 2.30 & 0.8069 & 5.00 & 0.0614 & 4.50 & 584 & 13 & 601 & 23 & 652 & 96 & 586 & 13 & 10.4 \\
\hline oc19g10 & ORENSE & 17 & 0.0951 & 2.04 & 0.8003 & 3.70 & 0.0612 & 2.02 & 586 & 11 & 597 & 17 & 646 & 44 & 586 & 11 & 9.3 \\
\hline oc14e14 & VV YELTES & 16 & 0.0960 & 1.36 & 0.7814 & 1.62 & 0.0589 & 1.28 & 591 & 8 & 586 & 7 & 562 & 28 & 588 & 7 & -5.2 \\
\hline oc14g12 & VV YELTES & 23 & 0.0997 & 1.84 & 0.8455 & 3.68 & 0.0610 & 2.64 & 613 & 11 & 622 & 17 & 640 & 58 & 611 & 11 & 4.2 \\
\hline ос13a05 & PONFERRADA & 28 & 0.0999 & 1.06 & 0.8332 & 2.14 & 0.0614 & 1.90 & 614 & 6 & 615 & 10 & 650 & 42 & 614 & 6 & 5.5 \\
\hline oc19g09 & ORENSE & 31 & 0.1003 & 2.12 & 0.8398 & 4.24 & 0.0601 & 3.50 & 616 & 12 & 619 & 20 & 608 & 74 & 616 & 12 & -1.3 \\
\hline oc14d08 & LAALBERCA & 31 & 0.1007 & 1.32 & 0.8259 & 1.60 & 0.0598 & 1.20 & 619 & 8 & 611 & 7 & 596 & 26 & 619 & 8 & -3.9 \\
\hline oc19b07 & RICOBAYO & 16 & 0.1010 & 1.68 & 0.8405 & 1.42 & 0.0629 & 2.08 & 620 & 10 & 619 & 7 & 702 & 44 & 619 & 7 & 11.7 \\
\hline oc15f14 & MERIDA & 26 & 0.1021 & 2.44 & 0.8838 & 6.86 & 0.0606 & 5.62 & 627 & 15 & 643 & 33 & 624 & 122 & 624 & 14 & -0.5 \\
\hline oc19g13 & ORENSE & 15 & 0.1025 & 2.80 & 0.8253 & 4.18 & 0.0593 & 2.14 & 629 & 17 & 611 & 19 & 578 & 46 & 622 & 15 & -8.8 \\
\hline oc19j14 & ORENSE & 24 & 0.1032 & 1.76 & 0.8856 & 3.44 & 0.0632 & 3.48 & 633 & 11 & 644 & 16 & 712 & 72 & 636 & 10 & 11.1 \\
\hline oc19c15 & RICOBAYO & 11 & 0.1040 & 2.54 & 0.9207 & 3.98 & 0.0635 & 3.26 & 638 & 15 & 663 & 19 & 724 & 70 & 638 & 15 & 11.9 \\
\hline oc22c05 & VVYELTES & 21 & 0.1057 & 1.58 & 0.8838 & 2.20 & 0.0605 & 2.30 & 648 & 10 & 643 & 10 & 622 & 50 & 646 & 8 & -4.2 \\
\hline oc14g16 & VV YELTES & 44 & 0.1108 & 1.12 & 0.9439 & 1.22 & 0.0617 & 1.10 & 678 & 7 & 675 & 6 & 664 & 24 & 676 & 6 & -2.1 \\
\hline \multicolumn{18}{|c|}{ Discordant analyses (pre-650 Ma) } \\
\hline oc $22 \mathrm{~d} 15$ & VV YELTES & 32 & 0.0840 & 4.90 & 1.0606 & 4.20 & 0.0933 & 3.50 & 520 & 25 & 734 & 22 & 1492 & 66 & & & \\
\hline oc19b14 & CIPEREZ & 36 & 0.0934 & 1.90 & 0.8522 & 3.60 & 0.0666 & 3.60 & 575 & 8 & 626 & 15 & 824 & 76 & & & \\
\hline oc14g14 & LAALBERCA & 25 & 0.4904 & 1.50 & 13.0925 & 3.22 & 0.1934 & 1.00 & 2572 & 40 & 2686 & 21 & 2770 & 12 & & & \\
\hline
\end{tabular}

i.s. = signal interval integrated for isotope-ratio and age calculation (in seconds).

disc\% = percent discordance calculated from ${ }^{207} \mathrm{~Pb} /{ }^{206} \mathrm{~Pb}$ and ${ }^{206} \mathrm{~Pb} /{ }^{238} \mathrm{U}$ ages (negative values: reversely discordant analyses).

Cadomian zircons have been consumed in earlier stages of melting (late Neoproterozoic, Cambrian and Ordovician magmatic events) of the lower crust (see also Fernandez-Suarez et al., 2006).
Finally, it ought to be said that a more comprehensive study of zircon inheritance in late Variscan granitoids and mafic rocks is necessary in order to further test the above ideas. 


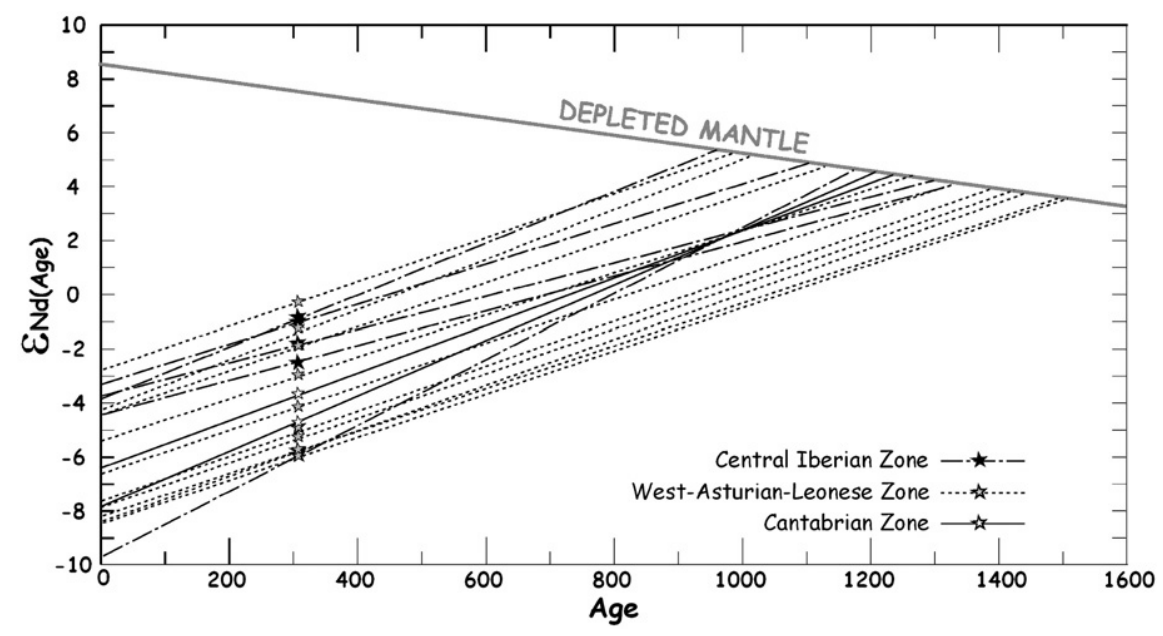

Fig. 6. Age vs. $\varepsilon_{\mathrm{Nd}}$ diagram. Stars are grey coded as in Fig. 2.

Supplementary materials related to this article can be found online at doi:10.1016/j.lithos.2010.09.010.

\section{Acknowledgments}

The authors wish to thank Francisco Pereira and David Schofield for constructive reviews and Jarda Dostal and Nelson Eby for their
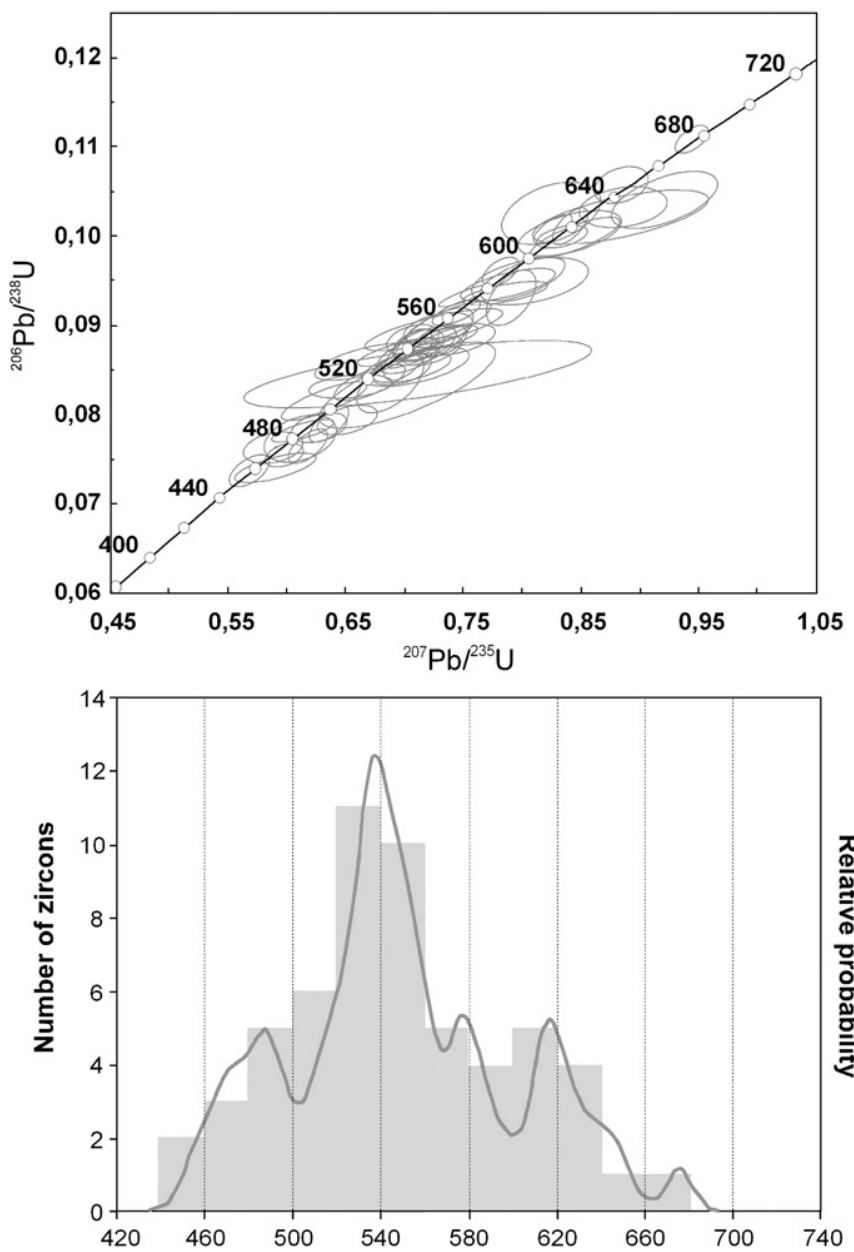

Fig. 7. Concordia plot and probability density histogram for inherited zircon ages (three pre-650 Ma analyses not included). editorial work. JFS wishes to acknowledge the financial support from project CONSOLIDER CGL2007-65338-C02-01/BTE by the Spanish Ministry of Science and Technology. GGA and DPG financial support was supplied by Research Projects ODRE and ODRE II ("Oroclines and Delamination: Relations and Effects") No. CGL2006-00902 and CGL2009-1367, from the Spanish Ministry of Science and Innovation. DPG is also granted by an ACPI grant from the Junta deCastilla yLeon.

\section{References}

Aramburu, C., 2002. El Paleozoico Inferior de la Zona Cantábrica. In: Rabano, I., Gutiérrez-Marco, J.C., Saavedra, J. (Eds.), El Paleozoico Inferior de Ibero-América. Universidad de Extremadura, pp. 397-421.

Arenas, R., Catalan, J.R.M., 2003. Low-P metamorphism following a Barrovian-type evolution. Complex tectonic controls for a common transition, as deduced in the Mondonedo thrust sheet (NW Iberian-Massif). Tectonophysics 365, 143-164.

Barreiro, J.G., 2006. Ar-40/Ar-39 laserprobe dating of mylonitic fabrics in a polyorogenic terrane of NW Iberia. Journal of the Geological Society 163, 61-73.

Bea, F., Montero, P.G., Gonzalez Lodeiro, F., Talavera, C., Molina, J.F., Scarrow, J.H., Whitehouse, M.J., Zinger, T., 2006. Zircon thermometry and U-Pb ion-microprobe dating of the gabbros and associated migmatites of the Variscan Toledo Anatectic Complex, Central Iberia. Journal of the Geological Society 163, 847-855.

Bea, F., Montero, P., Gonzalez-Lodeiro, F., Talavera, C., 2007. Zircon inheritance reveals exceptionally fast crustal magma generation processes in central iberia during the CambroOrdovician. Journal of Petrology 48, 2327-2339.

Castineiras, P., Villaseca, C., Barbero, L., Romera, C.M., 2008. SHRIMP U-Pb zircon dating of anatexis in high-grade migmatite complexes of Central Spain: implications in the Hercynian evolution of Central Iberia. International Journal of Earth Sciences 97, 35-50.

Castro, A., 2004. The source of granites: inferences from the Lewisian complex. Scottish Journal of Geology 40, 49-65.

Castro, A., Corretge, L.G., De la Rosa, J., Fernandez, C., Lopez, S., Garcia-Moreno, O., Chacon, H., 2003. The appinite-migmatite complex of Sanabria, NW Iberian massif, Spain. Journal of Petrology 44, 1309-1344.

Chappell, B.W., White, A.R.J., 1992. I- and S-type granites in the Lachlan Fold Belt. Transactions Royal Society Edinburgh 83, 1-26.

Dallmeyer, R.D., Ibarguchi, J.I.G., 1990. Age of amphibolitic metamorphism in the ophiolitic unit of the Morais allochthon (Portugal) - implications for early Hercynian orogenesis in the Iberian Massif. Journal of the Geological Society 147, 873-878.

Dallmeyer, R.D., Martinez Catalan, J.R., Arenas, R., Gil Ibarguchi, J.I., Gutierrez-Alonso, G., Farias, P., Bastida, F., Aller, J., 1997. Diachronous Variscan tectonothermal activity in the NW Iberian Massif: Evidence from Ar-40/Ar-39 dating of regional fabrics. Tectonophysics 277, 307-337.

Debon, F., Lefort, P., 1988. A cationic classification of common plutonic rocks and their magmatic associations - principles, method, applications. Bulletin de Minéralogie 111, 493-510.

DePaolo, D.J., 1981. Neodymium isotopes in the Colorado Front Range and crust mantle evolution in the Proterozoic. Nature 291, 193-196.

DePaolo, D.J., 1988. Neodymium isotope geochemistry: an introduction. Springer Verlag, New York. (187 pp).

Dias, G., Leterrier, J., Mendes, A., Simoes, P.P., Bertrand, J.M., 1998. U-Pb zircon and monazite geochronology of post-collisional Hercynian granitoids from the Central Iberian Zone (Northern Portugal). Lithos 45, 349-369.

Fernández-Suárez, J., 1994. Petrología de los granitos peralumínicos y metamorfismo de la banda Boal-Los Ancares, PhD Thesis, Universidad de Oviedo, Oviedo, 374 pp.

Fernandez-Suarez, J., Gutierrez-Alonso, G., Jenner, G.A., Jackson, S.E., 1998. Geochronology and geochemistry of the Pola de Allande granitoids (northern Spain): their bearing on 
the Cadomian-Avalonian evolution of northwest Iberia. Canadian Journal of Earth Sciences 35, 1439-1453.

Fernandez-Suarez, J., Gutierrez-Alonso, G., Jenner, G.A., Tubrett, M.N., 1999. Crustal sources in Lower Palaeozoic rocks from NW Iberia: insights from laser ablation U-Pb ages of detrital zircons. Journal of the Geological Society 156, 1065-1068.

Fernandez-Suarez, J., Dunning, G.R., Jenner, G.A., Gutierrez-Alonso, G., 2000a. Variscan collisional magmatism and deformation in NW Iberia: constraints from U-Pb geochronology of granitoids. Journal of the Geological Society 157, 565-576.

Fernandez-Suarez, J., Gutierrez-Alonso, G., Jenner, G.A., Tubrett, M.N., 2000b. New ideas on the Proterozoic-Early Palaeozoic evolution of NW Iberia: insights from U-Pb detrital zircon ages. Precambrian Research 102, 185-206.

Fernandez-Suarez, J., Arenas, R., Jeffries, T.E., Whitehouse, M.J., Villaseca, C., 2006. A U-Pb study of zircons from a lower crustal granulite xenolith of the Spanish central system: a record of Iberian lithospheric evolution from the Neoproterozoic to the Triassic. Journal of Geology 114, 471483.

Galan, G., Pin, C., Duthou, J.L., 1996. Sr-Nd isotopic record of multi-stage interactions between mantle-derived magmas and crustal components in a collision context - the ultramafic-granitoid association from Vivero (Hercynian belt, NW Spain). Chemical Geology 131, 67-91.

Gutierrez-Alonso, G., et al., 2003. Terrane accretion and dispersal in the northern Gondwana margin. An Early Paleozoic analogue of a long-lived active margin. Tectonophysics 365, 221-232.

Gutierrez-Alonso, G., Fernandez-Suarez, J., Weil, A.B., Murphy, J.B., Nance, R.D., Corfu, F., Johnston, S.T., 2008a. Self-subduction of the Pangaean global plate. Nature Geoscience 1, 549-553.

Gutiérrez-Alonso, G., Fernández-Suárez, J., Weil, A.B., 2004. Orocline triggered lithospheric delamination. In: Weil, A.B., Sussman, A. (Eds.), Paleomagnetic and structural analysis of orogenic curvature. Special Paper. Geological Society of America, Boulder, pp. 121-131.

Gutiérrez-Marco, J.C., 1999. Revisión bioestratigráfica de las pizarras del Ordovícico Medio en el noroeste de España (zonas Cantábrica, Asturoccidental-leonesa y Centroibérica septentrional). Acta Geologica Hispánica 34, 3-87.

Julivert, M., Marcos, A., Truyols, J., 1972. L'evolutión paléogéographique du nord-ouest de l'Espagne pendant l'Ordovicien-Silurien, Bulletin de la Societé Géologique et Minéralogique de Bretagne, pp. 1-7.

Klotzli, U.S., Koller, F., Scharbert, S., Hock, V., 2001. Cadomian lower-crustal contributions to variscan granite petrogenesis (South Bohemian pluton, Austria): constraints from zircon typology and geochronology, whole-rock, and feldspar Pb-Sr isotope systematics. Journal of Petrology 42, $1621-1642$.

Linnemann, U., Pereira, M.F., Jeffries, T., Drost, K., Gerdes, A., 2008. Cadomian orogeny and the opening of the Rheic Ocean: new insights in the diacrony of geotectonic processes constrained by LA-ICPMS U-Pb zircon dating (Ossa-Morena and Saxo-Thuringian Zones, Iberian and Bohemian Massifs)". Tectonophysics 361, 21-43.

Marcos, A., Farias, P., 1999. La estructura de las láminas inferiores del Complejo de Cabo Ortegal y su autóctono en el área de Chantada (Galicia, NO de España). Trabajos de Geología, Universidad de Oviedo 21, 201-218.

Martinez Catalan, J.R., Arenas, R., Garcia, F.D., Abati, J., 1997. Variscan accretionary complex of northwest Iberia: terrane correlation and succession of tectonothermal events. Geology 25, 1103-1106.

Martinez Catalan, J.R., Arenas, R., Balda, M.A.D., 2003. Large extensional structures developed during emplacement of a crystalline thrust sheet: the Mondonedo nappe (NW Spain). Journal of Structural Geology 25, 1815-1839.

Martinez Catalan, J.R., Fernandez-Suarez, J., Jenner, G.A., Belousova, E., Montes, A.D., 2004 Provenance constraints from detrital zircon U-Pb ages in the NW Iberian Massif: implications for Palaeozoic plate configuration and Variscan evolution. Journal of the Geological Society 161, 463-476.

Martinez Catalan, J.R., Arenas, R., Abati, J., Sanchez Martinez, S., Diaz Garcia, F., FernandezSuarez, J., Gonzalez Cuadra, P., Castineiras, P., Gomez Barreiro, J., Diez Montes, A., Clavijo, E Pascual, F.J., Andonaegui, P., Jeffries, T.E., Alcock, J.E., Diez Fernandez, R., Lopez Carmona, A., 2009. A rootless suture and the loss of the roots of a mountain chain: the Variscan Belt of NW Iberia Comptes Rendus Geoscience 341, 114-126.

Martínez Catalán, J.R., Arenas, R., Díaz García, F., Abati, J., 1999. Allochthonous units in the Variscan belt of NW Iberia. Terranes and accretionary history. In: Sinha, A.K. (Ed.), Basement Tectonics. Kluwer Academic Publishers, pp. 65-84.

Martínez Catalán, J.R., et al., 2007. Space and time in the tectonic evolution of the northwestern Iberian Massif. Implications for the comprehension of the Variscan belt. In: Hatcher Jr., R.D., Carlson, M.P., McBride, J.H., Martínez Catalán, J.R. (Eds.), 4-D framework of continental crust. Memoir. Geological Society of America, Boulder.

Mendia, M.S., Ibarguchi, J.I.G., 1991. High-grade metamorphic rocks and peridotites along the Leiza Fault (Western Pyrenees, Spain). Geologische Rundschau 80, 93-107.

Montero, P., Bea, F., Gonzalez-Lodeiro, F., Talavera, C., Whitehouse, M.J., 2007. Zircon ages of the metavolcanic rocks and metagranites of the Ollo de Sapo Domain in central Spain: implications for the neoproterozoic to early palaeozoic evolution of Iberia. Geological Magazine 144, 963-976.

Montero, P., Bea, F., Corretge, L.G., Floor, P., Whitehouse, M.J., 2009. U-Pb ion microprobe dating and $\mathrm{Sr}$ and $\mathrm{Nd}$ isotope geology of the Galineiro Igneous Complex A model for the peraluminous/peralkaline duality of the Cambro-Ordovician magmatism of Iberia. Lithos 107, $227-238$.

Morenoventas, I., Rogers, G., Castro, A., 1995. The role of hybridization in the genesis of Hercynian granitoids in the Gredos massif, Spain-inferences from Sr-Nd isotopes. Contributions to Mineralogy and Petrology 120, 137-149.

Murphy, J.B., Gutierrez-Alonso, G., Nance, R.D., Fernandez-Suarez, J., Keppie, J.D., Quesada, C., Strachan, R.A., Dostal, J., 2006. Origin of the Rheic Ocean: rifting along a Neoproterozoic suture? Geology 34, 325-328.
Murphy, J.B., Gutierrez-Alonso, G., Fernandez-Suarez, J., Braid, J.A., 2008. Probing crustal and mantle lithosphere origin through Ordovician volcanic rocks along the Iberian passive margin of Gondwana. Tectonophysics 461, 166-180.

Nance, R.D., Murphy, J.B., Strachan, R.A., Keppie, J.D., Gutierrez-Alonso, G., Fernandez-Suarez, J., Quesada, C., Linnemann, U., D'Lemos, R., Pisarevsky, S.A., 2008. Neoproterozoic-early Palaeozoic tectonostratigraphy and palaeogeography of the peri-Gondwanan terranes: Amazonian v. West African connections. In: Ennih, N.a.L., J.P. (Eds.), The Boundaries of the West African Craton. Geological Society, London, pp. 345-383.

Nance, R.D., Gutierrez-Alonso, G., Keppie, J.D., Linnemann, U., Murphy, J.B., Quesada, C., Strachan, R.A., Woodcock, N.H., 2010. Evolution of the Rheic Ocean. Gondwana Research 17, 194 222.

Orejana, D., Villaseca, C., Perez-Soba, C., Lopez-Garcia, J.A., Billstrom, K., 2009. The Variscan gabbros from the Spanish Central System: a case for crustal recycling in the sub-continental lithospheric mantle? Lithos 110, 262-276.

Pearce, J.A., Harris, N.B.W., Tindle, A.G., 1984. Trace element discrimination diagrams for the tectonic interpretation of granitic rocks. Journal of Petrology 25, 956-983.

Pereira, M.F., Chichorro, M., Williams, I.S., Silva, J.B., 2008. Zircon U-Pb geochronology of paragneisses and biotite granites from the SW Iberian Massif (Portugal): evidence for a paleogeographic link between the Ossa-Morena Ediacaran basins and the West African craton. In: Liégeois, J.P., Nasser, E. (Eds.), The boundaries of the West African Craton: Geological Society of London Special Publication, 297, pp. 385-408.

Pereira, M.F., Chichorro, M., Williams, I.S., Silva, J.B., Fernandez, C., Diaz-Azpiroz, M., Apraiz, A., Castro, A., 2009. Variscan intra-orogenic extensional tectonics in the Ossa-Morena Zone (Évora-AracenaLora del Río metamorphic belt, SW Iberian Massif): SHRIMP zircon U-Th-Pb geochronology. In: Murphy, B. (Ed.), Ancient and modern analogues: Geological Society of London Special Publication, 327, pp. 215-237.

Perez Estaun, A., Martinez Catalan, J.R., Bastida, F., 1991. Crustal thickening and deformation sequence in the footwall to the suture of the Variscan belt of Northwest Spain. Tectonophysics 191, 243-253.

Perez Estaun, A., et al., 1994. Crustal structure of the external Variscides in Northwest Spain from deep seismic-reflection profiling. Tectonophysics 232, 91-118.

Quesada, C., 1990. Precambrian terranes in the Iberian Variscan foldbelt. In: Strachan, R.A.T. G.K. (Eds.), Avalonian and Cadomian Geology of the North Atlantic. Blackie and Son, Glasgow, pp. 109-133.

Quesada, C., 1991. Terranes within the Iberian Massif: correlations with West African sequences. In: Dallmeyer, R.D.a.L., J.P. (Eds.), The West African Orogens and Circum-Atlantic Correlations. Springer Verlag, Berlin, pp. 267-294.

Ribeiro, A., Pereira, E., Dias, R., 1990. Structure in the NW of the Iberian Peninsula. In: Dallmeyer, R.D., Martínez-García, E. (Eds.), Pre-Mesozoic Geology of Iberia. Springer Verlag, Berlin, pp. 221-236.

Robardet, M., 2002. Alternative approach to the Variscan Belt in Southwestern Europe: preorogenic paleobiogeographical constraints. In: Martínez-Catalán, J.R., Hatcher, R.D., Arenas, R., Díaz García, F. (Eds.), Variscan-Appalachian dynamics: the building of the late Paleozoic basement. Geological Society of America Special Paper, pp. 1-15.

Robardet, M., 2003. The Armorica 'microplate': fact or fiction? Critical review of the concept and contradictory palaeobiogeographical data. Palaeogeography, Palaeo- climatology, Palaeoecology 195, 125-148.

Robardet, M., Gutiérrez-Marco, J.C., 2004. The Ordovician, Silurian and Devonian sedimentary rocks of the Ossa-Morena Zone (SW Iberian Peninsula, Spain). Journal of Iberian Geology 30, 73-92.

Sanchez-Garcia, T., Quesada, C., Bellido, F., Dunning, G.R., del Tanago, J.G., 2008. Two- step magma flooding of the upper crust during rifting: the Early Paleozoic of the Ossa Morena Zone (SW Iberia). Tectonophysics 461, 72-90.

Sanchez-Garcia, T., Bellido, F., Pereira, M.F., Chichorro, M., Quesada, C., Pin, Ch., Silva, J.B., 2010. Riftrelated volcanism predating the birth of the Rheic Ocean (Ossa-Morena zone, SW Iberia). Gondwana Research 17, 392-407.

Solá, A.R., Pereira, M.F., Williams, I.S., Ribeiro, M.L., Neiva, A.M.R., Montero, B., Bea, F., Zinger, T., 2008. New insights from U-Pb zircon dating of Early Ordovician magmatism on the northern Gondwana margin: The Urra Formation (SW Iberian Massif, Portugal). Tectonophysics 461, 114-129.

Suarez, O., Corretge, L.G., Galan, G., 1990. Distribution and characteristics of Hercynian metamorphism. In: Dallmeyer, R.D.A.M.G., Dallmeyer, E. (Eds.), Pre-Mesozoic Geology of Iberia. Springer Verlag, Berlin, pp. 129-133.

Suarez, O., Cuesta, A., Corretge, G., Fernandez-Suarez, J., 1992. Spinel-bearing inclusions in calc-alkaline granitoids of the Cantabrian and West Asturian Leonese Zones, Hercynian Iberian belt. Bulletin de la Societe Geologique de France 163, 611-623.

Sun, S.-S., McDonough, W.F., 1989. Chemical and isotopic systematics of oceanic basalts: implications formantle composition and processes. In: Norry, S.A.D., Norry,

M.J.(Eds.), Magmatism in the oceanic basins. Geological Society of London, London, pp. 313-345 (Special Publication)

Ugidos, J.M., Valladares, M.I., Recio, C., Rogers, G., Fallick, A.E., Stephens, W.E., 1997. Provenance of Upper Precambrian Lower Cambrian shales in the Central Iberian Zone, Spain: evidence from a chemical and isotopic study. Chemical Geology 136, 55-70.

Villaseca, C., Barbero, L., Herreros, V., 1998. A re-examination of the typology of peraluminous granite types in intracontinental orogenic belts. Transactions of the Royal Society of Edinburgh-Earth Sciences 89, 113-119.

Villaseca, C., Downes, H., Pin, C., Barbero, L., 1999. Nature and composition of the lower continental crust in central Spain and the granulite-granite linkage: inferences from granulitic xenoliths. Journal of Petrology 40, 1465-1496.

Villaseca, C., Bellido, F., Perez-Soba, C., Billstrom, K., 2009. Multiple crustal sources for posttectonic I-type granites in the Hercynian Iberian Belt. Mineralogy and Petrology 96, 197211.

Viruete, J.E., 1998. Relationships between structural units in the Tormes gneiss dome (NW Iberian massif, Spain): geometry, structure and kinematics of contractional and extensional Variscan deformation. Geologische Rundschau 87, 165-179. 
Viruete, J.E., Arenas, R., Martinez Catalan, J.R., 1994. Tectonothermal evolution associated with Variscan crustal extension in the Tormes gneiss Dome (NW Salamanca, Iberian Massif, Spain). Tectonophysics 238, 117-138.

Weil, A.B., van der Voo, R., van der Pluijm, B.A., 2001. Oroclinal bending and evidence against the Pangea megashear: the Cantabria-Asturias arc (northern Spain). Geology 29, 991994

Weil, A., Gutierrez-Alonso, G., Conan, J., 2010. New time constraints on lithospheric- scale oroclinal bending of the Ibero-Armorican Arc: a palaeomagnetic study of earliest Permian rocks from Iberia. Journal of the Geological Society 167, 127-143.
Woodcock, N.H., Soper, N.J., Strachan, R.A., 2007. A Rheic cause for the Acadian deformation in Europe. Journal of the Geological Society 164, 1023-1036.

Zeck, H.P., Wingate, M.T.D., Pooley, G.D., Ugidos, J.M., 2004. A sequence of Pan-African and Hercynian events recorded in zircons from an orthogneiss from the Hercynian belt of western central Iberia - an ion microprobe U-Pb study. Journal of Petrology 45, 1613-1629. 